\title{
FENOLOGIA E MORFOLOGIA REPRODUTIVAS DE ECÓTIPOS DE Brachiaria spp.
}

\section{MARCO ANTONIO DE SOUZA \\ Engenheiro Agrônomo}

Orientador: Prof. Dr. SILVIO MOURE CICERO

Dissertação apresentada à Escola Superior de Agricultura "Luiz de Queircz", da Universidade de São Paulo, para obtenção do título de Mestre em Agronomia. Área de concentração : Fitotecnia.

\section{PIRACICABA}

Estado de São Paulo - Brasil

Maio - 1995 
EATALDGGSAO HA PUELICACAE

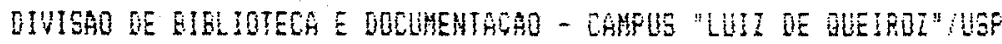

\section{Souza, Harco Antonio de}

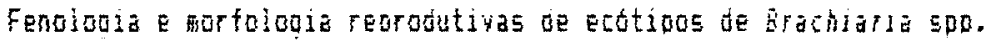
firacicaba. 1995.

850. ilus.

Dise. (hestre) - Esale

Hibligarafia.

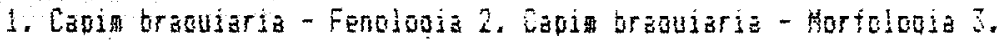

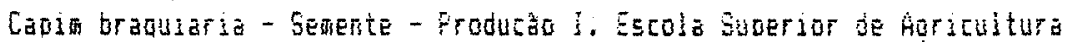
Luz de Gueiroz. Firacicata 
FENOLOGIA E MORFOLOGIA REPRODUTIVAS DE ECÓTIPOS DE Brachiaria spp.

MARCO ANTONIO DE SOUZA

Aprovada em : 29.06 .95

Comissão julgadora:

Prof. Dr. Silvio Moure Cicero

ESALQ/USP

Prof. Dr. Francisco Ferraz de Toledo

ESALQ/USP

Dr. Ronaldo Pereira de Andrade

CPAC/EMBRAPA

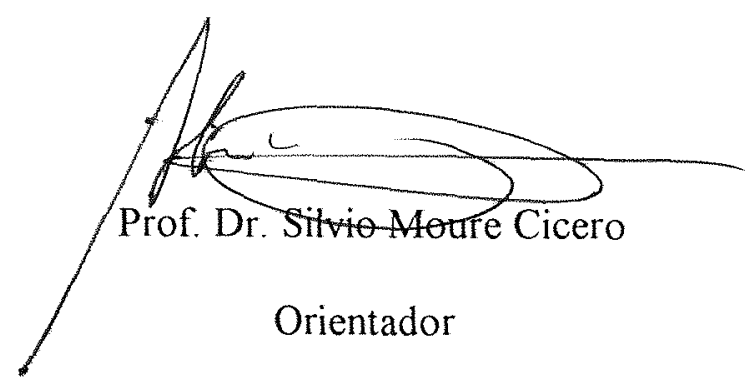


"É melhor lançar-se à luta,

em busca do sucesso,

mesmo expondo-se ao insucesso,

do que formar na fila com os pobres de espírito,

que não gozam muito,

nem sofrem muito,

mas vivem nessa penumbra cinzenta,

sem conhecer nem vitória,

nem derrota."

(Franklin Delano Roosevelt)

A meus pais, João Batista (in memoriam) e Eudóxia, pelo amor, incentivo e compreensão.

A meus irmãos, José Paulo, Lúcio Flávio, Sônia, João Deon e Júlia, por existirem. 


\section{AGRADECIMENTOS}

A Deus, por mais esta oportunidade.

À Empresa Brasileira de Pesquisa Agropecuária - EMBRAPA, e ao Centro de Pesquisa Agropecuária doa Cerrados - CPAC, pelo investimento e oportunidade concedida.

À ESALQ/USP, pelo curso oferecido.

Ao Professor Dr. Silvio Moure Cicero, pela orientação.

Ao Prof. Dr. Francisco Ferraz de Toledo e Dr. Ronaldo Pereira de Andrade, pela participação na banca examinadora e pelas consultas durante a realização deste trabalho.

Aos professores e funcionários da ESALQ, particularmente aos do Setor de Tecnologia de Sementes do Departamento de Agricultura, pelo apoio e amizade.

Aos funcionários do Centro de Pesquisa Agropecuária dos Cerrados - CPAC, pelo suporte na conclusão deste trabalho.

Aos colegas da ATPA-CPAC, pelo incentivo e apoio.

À Sementes Oeste Paulista, pela concessão das sementes comerciais.

Aos colegas e amigos de curso e da ESALQ, pelo convívio sadio e solidário.

A todos de Piracicaba, pela hospitalidade.

Aos amigos de Juazeiro, Londrina, São Paulo, Recife e Brasilia, pelo carinho e afeto.

A todos, que de alguma forma contribuíram para a realização deste trabalho, agradeço de coração. 


\section{SUMÁRIO}

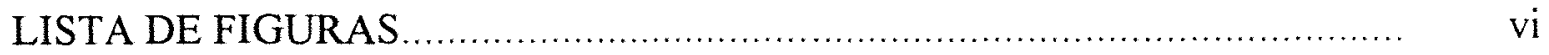

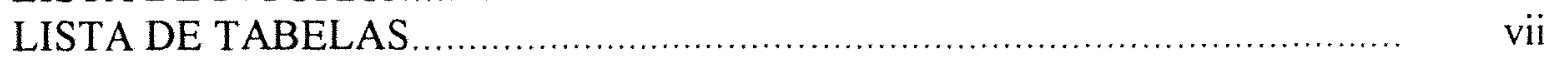

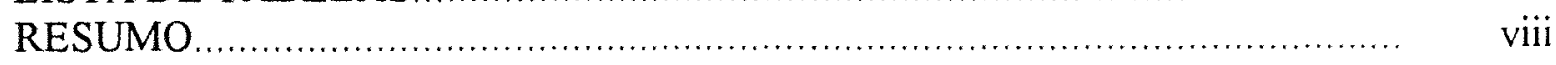

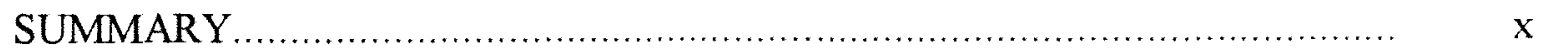

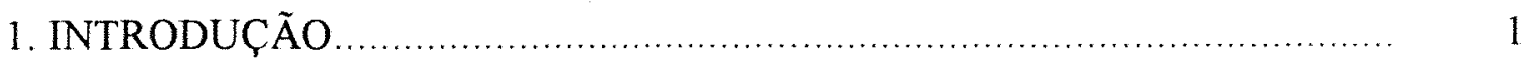

2. REVISÃO DE LITERATURA

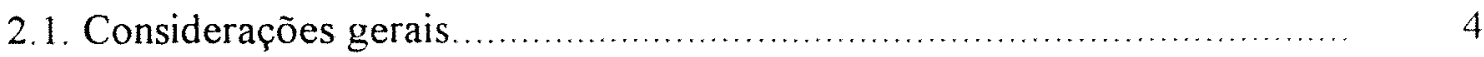

2.2. Introdução e avaliação de germoplasma .............................................. 5

2.3. Problemas na produção de sementes de gramineas forrageiras................ 12

2.4. O gênero Brachiaria

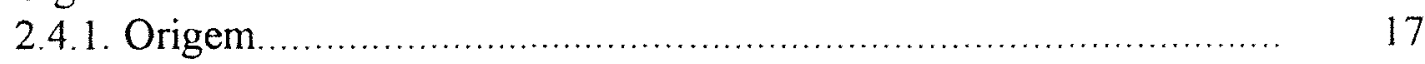

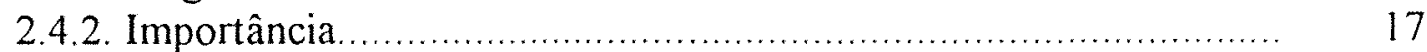

2.4.3. Características botânicas ........................................................... 23

2.5. Fenologia reprodutiva e componentes da produção de sementes............. 29

2.5.1. Requerimentos climáticos ................................................. 30

2.5.2. Fenologia reprodutiva ...................................................... 33

2.5.3. Componentes da produção de sementes ..................................... 35

2.6. Qualidade de sementes.......................................................... 38

3. MATERIAL E MÉTODOS

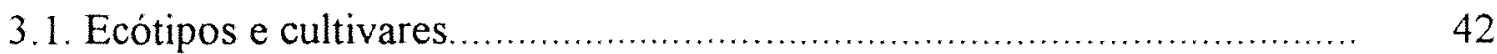

3.2. Localização e instalação do experimento ............................................... 43

3.3. Coleta de dados
3.3.1. Fenologia reprodutiva.

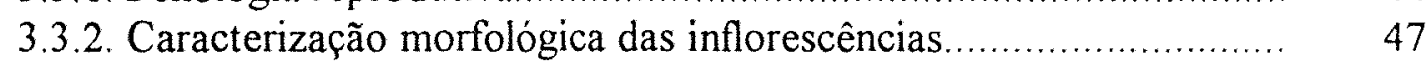

3.3.3. Componentes da produção de sementes..................................... 49

3.3.4. Qualidade das sementes....................................................... 51

4. RESULTADOS E DISCUSSÃO

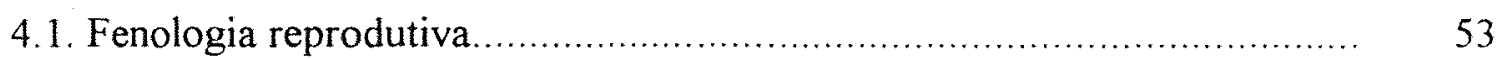

4.2. Caracterização morfológica das inflorescências...................................... 62

4.3. Componentes da produção de sementes............................................... 65

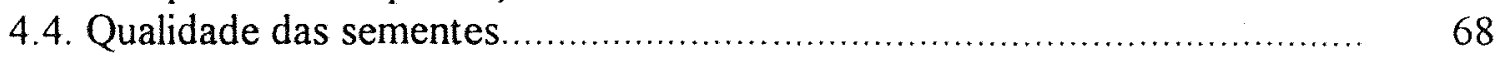

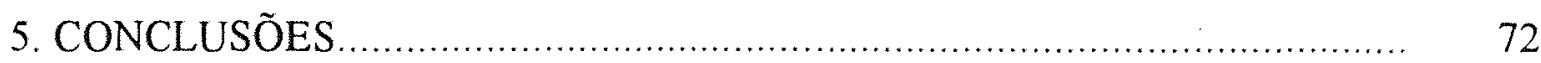

6. REFERÊNCIAS BIBLIOGRÁFICAS ................................................. 74 


\section{LISTA DE FIGURAS}

Figura

Página

1. Características da produção de sementes de gramíneas tropicais

2. Centros de diversificação dos gêneros Andropogon, Brachiaria, Cenchrus e de Panicum maximum.

3. Coletor de sementes

4. Esquema ilustrativo de instalação do coletor de sementes no campo.

5. Vista lateral do racemo, com espiguetas e primórdios de espiguetas

6. Referenciais para caracterização morfológica das inflorescências.

7. Vista ventral de parte da ráquis após degrana, com pedicelos de espiguetas e pedicelos de primórdios de espiguetas.

8. Inicio de emissão de inflorescências, no primeiro e segundo ano de florescimento, de ecótipos de Brachiaria spp.

9. Fenologia reprodutiva de ecótipos de Brachiaria spp. no segundo ano de florescimento

10. Fotoperíodo durante as fenofases reprodutivas de ecótipos de Brachiaria spp., no segundo ano de florescimento.

11. Média semanal de precipitação pluvial e temperatura média, durante as fenofases reprodutivas de ecótipos de Brachiaria spp., no segundo ano de florescimento.

12. Média semanal de radiação solar global e umidade relativa do ar, durante as fenofases reprodutivas de ecótipos de Brachiaria spp., no segundo ano de florescimento 


\section{LISTA DE TABELAS}

Tabela

1. Germoplasma caracterizado

2. Data de início de emissão de inflorescências de ecótipos de Brachiaria spp., no primeiro ano de florescimento.

3. Data de inicio de emissão de inflorescências de ecótipos de Brachiaria spp., no primeiro e segundo ano de florescimento.

4. Fenologia reprodutiva de ecótipos de Brachiaria spp. no segundo ano de florescimento

5. Número de dias entre fenofases reprodutivas de ecótipos de Brachiaria spp., no segundo ano de florescimento

6. Características morfológicas das inflorescências de ecótipos de Brachiaria spp.

7. Componentes da produção de sementes, por inflorescência, de ecótipos de Brachiaria spp.

8. Número de sementes por grama e peso de 100 sementes de ecótipos de Brachiaria spp.

9. Resultados de teste de germinação e de tetrazólio em sementes de ecótipos de Brachiaria spp.

10. Amplitude, média e desvio padrão dos caracteres analisados, no segundo ano de florescimento 


\section{FENOLOGIA E MORFOLOGIA REPRODUTIVAS DE ECÓTIPOS DE}

Brachiaria spp.

Autor: MARCO ANTONIO DE SOUZA

Orientador: Prof. Dr. SILVIO MOURE CICERO

\section{RESUMO}

A fenologia e morfologia reprodutivas de germoplasma selecionado de Brachiaria brizantha (Hochst. ex A. Rich.) Stapf (ecótipos BRA 002801, 003361, 003441, 003484, 003891 e cv. Marandu) e Brachiaria decumbens Stapf (ecótipo BRA 004391 e cv. Basilisk) foi descrita a fim de caracterizar o mesmo, visando fornecer informações básicas relacionadas com a sua fase reprodutiva.

As parcelas foram estabelecidas na Escola Superior de Agricultura "Luiz de

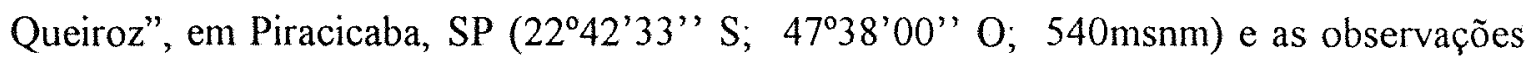
foram feitas após o início da emissão de inflorescências.

Durante o segundo ano de cultivo, com base na data de início de emissão de inflorescências (IEl) e no número de dias após corte de uniformização (ND), os materiais foram classificados em: precoces (B. decumbens cv. Basilisk e BRA 004391, $B$. brizantha BRA 003891 e 002801) com IEI anterior a 23/dez. ou ND $<70$; medianas ( $B$ brizantha $\mathrm{cv}$. Marandu, BRA 003361 e 003484) com IEI entre 01-10/fev. ou ND entre 
110-120; e tardias (B. brizantha BRA 004308 e 003441) com IEI após 12/abr. ou ND > 180 dias.

O florescimento no segundo ano ocorreu mais cedo, se comparado com o ano de estabelecimento, demonstrando a presença de uma fase de juvenilidade.

Entre os materiais, o pleno florescimento variou de 16/dez. a 13/mai. ou ND de 62 a 210, o início de degrana variou de 30/dez. a 31/mai. ou ND de 76 a 228 e o fim de degrana variou de 04/fev. a 15/jul. ou ND de 112 a 273.

Os caracteres morfológicos: número de racemos por inflorescência; comprimento do racemo; e número de espiguetas por racemo, variaram de 3 a $7 ; 6,8$ a $14,6 \mathrm{~cm}$; e 31 a 40 , respectivamente.

A porcentagem de sementes puras (espiguetas com cariopse) produzidas, em função do potencial total de produção por inflorescência, variou de 9 a $45 \%$. A porcentagem de aborto, em função do total de espiguetas desenvolvidas, variou de 53 a $88 \%$.

A qualidade das sementes foi analisada através de testes de germinação e de tetrazólio.

O presente trabalho demonstrou a presença de uma grande variabilidade, dentro e entre os ecótipos analisados, seja quanto a caracteres de fenologia e morfologia reprodutivas, como de componentes da produção de sementes. 


\title{
REPRODUCTIVE PHENOLOGY AND MORPHOLOGY OF Brachiaria spp. ECOTYPES
}

\author{
Author: MARCO ANTONIO DE SOUZA \\ Advisor: Prof. Dr. SILVIO MOURE CICERO
}

\section{SUMMARY}

The phenology and morphology of the reproductive phase of selected germplasm of Brachiaria brizantha (Hochst. ex A. Rich) Stapf (BRA 002801, 003361, 003441, 003484, 003891 and cv. Marandu) and Brachiaria decumbens Stapf (BRA 004391 and $\mathrm{cv}$. Basilisk), were described and characterized.

The experiment was established at the Escola Superior de Agricultura "Luiz de Queiroz", in Piracicaba, SP $\left(22^{\circ} 42^{\prime} 33^{\prime \prime} \mathrm{S}\right.$; $47^{\circ} 38^{\prime} 00^{\prime \prime} \mathrm{W}$; at $\left.540 \mathrm{masl}\right)$ and the data collection started after the beginning of inflorescence emission.

Based on the date of the beginning of inflorescence emission (BIE) and on the number of days after an uniformization cut (ND) observed on a second year crop the accessions were classified in: earlier (B. decumbens cv. Basilisk and BRA 004391, B. brizantha BRA 003891 and 002801) presenting BIE before December 23 or ND < 70; medium (B. brizantha $\mathrm{cv}$. Marandu, BRA 003361 and 003484) presenting BIE between 
February 01 to 10 or ND between $110-120$; and late (B. brizantha BRA 004308 and 003441) with BIE after April 12 or a ND bigger than 180.

Compared to the establishment year, flowering happened at earlier dates during the second year, indicating the existence of a juvenile phase.

Among the evaluated material, the date for peak flowering ranged between December 16 and May 13 or a ND of 62 to 210 . Seed shattering started between December 30 to May 31 or a ND range of 76 to 228 , while the end of seed shattering happened from February 04 to July 15 or a ND ranging from 112 to 273.

The morphological parameters: number of racemes per inflorescence, raceme length and spikelet number per raceme ranged, respectively, from 3 to $7 ; 6,8$ to $14,6 \mathrm{~cm}$; and 31 to 40 .

Considering the potential number of spkiletes sites in an inflorescence, the percentage of those containing a caryopse varied from 9 to $45 \%$. Considering the number of fully developed spikeletes the abortion rate ranged from 53 to $88 \%$

Seed quality was measured by germination and tetrazolium tests.

The data showed the existence of variability among and within the ecotypes for the reproductive morphology and phenological parameters, and for seed yield components. 


\section{INTRODUCCĀO}

A cada minuto que passa, a população mundial aumenta em 164 pessoas e, ao final de um dia, serão 236.160 novos seres, havendo segundo CHRISTIANSEN (1994) previsão de que a população dos paises em desenvolvimento dobre entre os anos de 1990 e 2025, tornando-se indispensável que se desperte para as pressões sociais e econômicas que certamente acompanham o aumento acelerado da população do globo terrestre.

Os trópicos apresentam mais de 1,6 bilhões de hectares de terras aráveis, reunindo os maiores recursos mundiais em terra e água para permitir o aumento no suprimento de alimentos. No entanto, é também nos trópicos onde ocorrem os maiores problemas com a alimentação humana.

$\mathrm{Na}$ América Latina tropical existem cerca de 850 milhões de hectares de savanas e florestas úmidas, assentadas sobre solos ácidos e de baixa fertilidade, cuja maior parte se localizam no Brasil. São os Cerrados que apesar de constituir a mais válida e atual opção para ampliação da fronteira agrícola do país, ainda apresentam o seu efetivo aproveitamento dependente de um melhor conhecimento da sua potencialidade.

Há mais de um século, em 1885, a publicação "Herds Dairyman" já registrava: "Quando nenhum tipo de vaca consegue produzir bem, recebendo alimento de baixa qualidade e escasso, sem manejo correto, qual a validade genética de tantos 
cruzamentos de raças? Simplesmente sobreviver ao tratamento imposto? As vacas são mantidas para observar qual a pior situação que estas suportam, ou para produzir lucros?"

Dentro desse contexto, o gênero Brachiaria vem se incorporando como forrageira de expressão no Brasil desde a década de 70 , devido à notável capacidade de domínio ecológico, adaptando-se desde solos úmidos e férteis até solos ácidos e de baixa fertilidade, sujeitos a secas estacionais, como os dos cerrados (SANTOS \& AGUIAR, 1985).

Atualmente, as espécies $B$. brizantha e $B$. decumbens representam a maioria das pastagens cultivadas no país, equivalendo a aproximadamente 40 milhões de hectares, sendo o gênero responsável ainda por cerca $70 \%$ do volume total de sementes de forrageiras comercializado anualmente no Brasil, e deste total, $90 \%$ corresponde às duas espécies (ZIMMER et al., 1994).

$\mathrm{Na}$ constante busca por materiais melhor adaptados às diversas condições edafoclimáticas e bióticas, principalmente na região central do Brasil, a introdução de germoplasma é uma prática que vem sendo implementada, gerando resultados satisfatórios. No entanto, a avaliação e seleção de tal material tem se baseado principalmente em aspectos relacionados com a produção de forragem, negligenciando de certa forma caracteres relacionados com a produção de sementes do mesmo.

Nessa busca, utilizando as palavras de VALLE et al. (1986) as perspectivas são auspiciosas pois, da variabilidade da coleção de Brachiaria deverão surgir novas cultivares, que promoverão uma maior diversificação das pastagens, com todos os beneficios dela decorrentes, como por exemplo, menor risco de disseminação de pragas e doenças, melhor aproveitamento de diferentes tipos de solos, ou mesmo a utilização mais racional dos vários ecótipos pelas diversas categorias animais. 
A atividade de produção de sementes de espécies do gênero Brachiaria apresenta diversos desafios, sejam eles de ordem fisiológica, morfológica ou tecnológica, cuja solução ou minimização dependem em primeiro lugar, do conhecimento do material que se pretende produzir, incluindo-se aspectos da fenologia e dos componentes da produção de sementes dos mesmo.

A caracterização reprodutiva do material selecionado nas primeiras etapas do processo de avaliação é de suma importância pois fornecerá subsídios valiosos às seleções futuras, bem como para programas de melhoramento genético, onde aspectos relacionados com a produção de sementes sejam analisados em conjunto com a produção de forragem dentre outros, de modo que os materiais selecionados tenham maiores possibilidades de sucesso junto aos seus usuários.

Segundo definição de SALOMON (1978), pesquisas exploratórias e descritivas são as que têm por objetivos: definir melhor o problema, proporcionar as chamadas intuições de solução, descrever comportamentos de fenômenos, além de definir e classificar fatos e variáveis, sendo que tais estudos não atingem ainda o nível da explicação nem o da predição, encontrados nas pesquisas "puras"ou "teóricas", nem do diagnóstico e/ou solução adequada de questões, obtidos nas pesquisas "aplicadas".

O presente trabalho, definido como exploratório e descritivo, tem como objetivo, caracterizar a fenologia e morfologia reprodutivas de ecótipos de Brachiaria spp., nas condições de Piracicaba, SP. 


\section{REVISĀO DE LITERATURA}

\subsection{Considerações gerais}

Aproximadamente metade do rebanho mundial sob pastejo encontra-se em regiões tropicais. No entanto, o desempenho do animal nestes locais, está muito aquém do obtido nas demais regiões pastoris (HUMPHREYS, 1987).

De acordo com LEITE \& EUCLIDES (1994) no Brasil Central, a exploração pecuária baseava-se inicialmente na utilização extensiva de pastagens nativas, principalmente dos estratos herbáceos e arbustivos dos campos cerrados.

Atualmente a atividade pecuária no Brasil, ocupa cerca de 221 milhões de hectares, sendo que destes, somente 75 milhões de ha ou $42 \%$, correspondem a pastagens cultivadas. Desse total cultivado, 47 milhões de ha ou $63 \%$, encontram-se localizados nas regiões Sudeste e Centro-Oeste (FIBGE, 1985). O rebanho bovino nacional equivale a 152 milhões de cabeças, sendo que as regiões Sudeste e Centro-Oeste possuem 85 milhões cabeças, representando 56\% do efetivo do país (FIBGE, 1993).

Segundo BARCELLOS \& VILELA (1994) a pecuária desenvolvida em áreas tipicamente tropicais do Brasil, abriga cerca de $80 \%$ do rebanho nacional e nesta região, 
o Brasil Central desponta com a maior representação, em termos percentuais, na atividade pecuária de corte.

É inegável a importância de tal atividade na região tropical do Brasil e com ela a necessidade da pesquisa em forragicultura. Entretanto, ISON \& HOPKINSON (1985) alertaram para o fato de que a pesquisa cientifica de pastagens tropicais, além de recente, tem direcionados esforços para as pesquisas aplicadas, deixando o conhecimento sobre fisiologia reprodutiva de diversas espécies forrageiras num estágio bastante primitivo.

ALCÂNTARA (1987) salientou que a maioria dos trabalhos científicos abordam as plantas forrageiras e, particularmente o gênero Brachiaria, ora pelos aspectos morfológicos/botânicos, ora pelas propriedades agronômicas de interesse forrageiro, quase nunca englobando os dois aspectos em um mesmo contexto. Assim sendo, as informações disponíveis quase nunca se completam, sendo exatamente por esse motivo que estudos sobre morfologia são encarados como essencialmente acadêmicos, sem que na verdade haja necessidade dessa dissociação entre teoria e prática.

\subsection{Introdução e avaliação de germoplasma}

Um dos fatores mais estimulantes no estudo dos seres vivos é a constatação de sua grande diversidade genética. De fato, é surpreendente a quantidade de formas, tanto animais como vegetais, que representam um manancial inesgotável para os mais variados estudos (PATERNIANI, 1988).

Em um alerta, PASCHOAL (1987) ressaltou que a seleção feita pelos antigos agricultores do Terceiro Mundo permitiu uma fantástica diversidade de culturas, 
necessária à sobrevivência. Por outro lado, a seleção moderna, feita pelos países desenvolvidos, eliminou a diversidade em favor da maior produtividade e uniformidade genética, aumentando a vulnerabilidade às pragas, doenças e condições físico-químicas do ambiente, ameaçando de fome a humanidade. Esse autor acrescentou ainda, que devido a essa maior suscetibilidade das variedades modernas, há necessidade constante de novos materiais genéticos, para compensar as mutações e os frequentes desequilibrios biológicos de pragas e patógenos.

A variabilidade existente no germoplasma forrageiro é considerável e USBERTI FILHO (1992) explicou que durante o processo evolutivo, as gramineas forrageiras adiquiriram um sistema especial de reprodução assexuada, denominado apomixia, que permite a rápida colonização de habitats disponiveis, através da formação de grupos enormes de indivíduos geneticamente semelhantes, muito bem adaptados às condições ambientais existentes, sendo essas populações denominadas de ecótipos.

O mesmo autor, didaticamente esclarece que no processo de formação de ecótipos, as gramíneas forrageiras apresentam, em condições naturais, os chamados "ciclos sexuais", caracterizados pelo aumento da taxa de reprodução via sexual, ativados sempre que as condições ambientais apresentem modificações sensiveis. Desta maneira, são produzidos novos genótipos através de segregação, sobre os quais a seleção natural age pela preservação daqueles mais adaptados às novas condições e, consequentemente, eliminação dos tipos com baixo potencial adaptativo. Após o processo seletivo, as populações recém formadas retornam ao processo de reprodução predominantemente assexual, o que acarreta a fixação dos genótipos selecionados. Afirmou ainda, que por este motivo, é comum encontrar-se em diversos gêneros, entre eles Brachiaria, grande variação entre populações/ecótipos e muito pequena variabilidade dentro dos mesmos. 
SCHULTZE-KRAFT (1980) afirmou que desde que se reconheceu que a alimentação do gado é o principal fator limitante para a produtividade pecuária no trópico sul americano, o interesse nas pesquisas sobre plantas forrageiras e a importância de desenvolver variedades novas e mais produtivas tem aumentado de maneira consideravel, sendo que atualmente, agrostólogos em muitos países tem implementado esforços para identificar gêneros, espécies e ecótipos de plantas forrageiras, que estejam melhor adaptadas às condições dos diversos ecossistemas do trópico sul americano.

Através de uma afirmação e um questionamento, SAVIDAN (1986) citou que no futuro o gado continuará se alimentando de capim. Então, quer seja geneticamente quer seja pelas introduções e avaliações de outros germoplasmas, qual será a nossa capacidade de melhorá-lo?

Existem essencialmente duas possibilidades de obtenção de novas variedades de forrageiras. A primeira consiste em selecionar, diretamente da variabilidade natural, aqueles genótipos que reunem as características desejadas, multiplicar suas sementes e liberá-las ao público. A segunda, a longo prazo, baseia-se na criação de novos genótipos, através de cruzamentos, a fim de serem avaliados, selecionados e depois liberados. Ambas atividades requerem ampla diversidade de germoplasma, bem como o acúmulo de conhecimentos básicos sobre o mesmo (VALLE \& MILES, 1994).

GIACOMETTI (1988) definiu a introdução de germoplasma como sendo a transferência ordenada e sistemática de materiais biológicos para um novo local, a fim de atender às necessidades do melhoramento genético e pesquisas correlatas, sendo que o material introduzido em uma nova área deverá passar por um processo de avaliação que indicará a sua adaptabilidade. 
Segundo Bogdan', citado por VALLE \& MILES (1994), ocorreram introduções esporádicas de poucos genótipos de plantas forrageiras até meados de 1960, que, por apresentarem excelente adaptação aos solos pobres e ácidos, boa produção e qualidade de matéria seca e farta produção de sementes, obtiveram grande aceitação por parte dos pecuaristas nacionais.

De acordo com VALLS (1988), o Brasil situa-se entre os países com maior diversidade genética disponível para pesquisa agrícola e correlata, sendo que o uso desta ainda é incipiente. A falta de informação adequada sobre essa variabilidade é uma das principais causas do uso limitado de ecótipos mantidos em bancos de germoplasma. O incremento de atividades de caracterização e avaliação de germoplasma, através da cooperação entre coordenadores de germoplasma, responsáveis por coleções e melhoristas, é apontada como maneira de superar a atual falta de informações. O autor ressalta ainda que a correta identificação botânica, a elaboração cuidadosa do cadastro de acessos, a caracterização fenológica e morfológica, a avaliação preliminar e a avaliação aprofundada, geralmente de cunho agronômico, são etapas essenciais do processo, que podem e, às vezes devem, ser complementadas pela caracterização reprodutiva ou bioquímica.

A expansão do uso de variedades melhoradas de forrageiras, depende acima de tudo da continua disponibilidade de sementes ou de material vegetativo, que tenha as caracteristicas do material original, seja livre de plantas invasoras e capaz de estabelecer boa pastagem. A maioria das plantas forrageiras tropicais não são domesticadas e tampouco selecionadas quanto a características de boa produção de sementes (YADAVA et al., 1984).

\footnotetext{
${ }^{\prime}$ BOGDAN, A. V. Tropical pasture and fodder plants. Longman, New York, 1977. 455p.
} 
Segundo USBERTI FILHO (1992) o sucesso de qualquer programa de melhoramento genético depende, em grande parte, da presença de suficiente variabilidade genética, que possa ser explorada com eficiência para a seleção de materiais com características desejáveis, sendo também importante para o melhorista o conhecimento aprofundado da espécie que está sendo trabalhada, como a biologia reprodutiva e a variabilidade natural, sempre tendo em mente um tipo ideal de planta dependendo do uso que se pretende dar à mesma, como objetivo a ser atingido.

SEIFFERT (1980) citou como exemplo do perigo da uniformidade genética, aliada à incapacidade de gerar novos genótipos, devido à apomixia, o desaparecimento de B. decumbens cv. Basilisk na Amazônia, devido à sua suscetibilidade à cigarrinha-daspastagens (Homoptera-Cercopidae).

Segundo LLERAS (1988) a diversidade genética dentro e entre populações vegetais está bem documentada e a importância de pesquisas sobre o assunto é um tema recorrente em diversas publicações, como ALLARD (1970), JAIN (1975), MARSHAL \& BROWN (1975 e 1983) e LLERAS et al. (1984). Devemos esclarecer, no entanto, que a afirmação do autor refere-se principalmente a grandes culturas, sendo que para plantas forrageiras, a variabilidade existente é ainda pouco documentada e pesquisada.

$\mathrm{O}$ incremento das atividades de caracterização e avaliação do amplo germoplasma hoje reunido, deve se impor entre as prioridades na estratégia de abordagem e manejo de recursos genéticos no Brasil. Uma vez superadas as deficiências de informação, o germoplasma disponivel será mais útil para os programas de melhoramento e a evidência clara dessa utilidade, seguramente apoiará as justificativas para o trabalho global com recursos genéticos (VALLS, 1988).

Segundo ARONOVICH \& ROCHA (1985) a introdução de novas espécies forrageiras, mais adaptadas às condições de solos ácidos e de baixa fertilidade, a partir 
dos anos 70, bem como o desenvolvimento de novas técnicas de formação de pastagens, possibilitaram a substituição da vegetação nativa por outras espécies forrageiras mais produtivas.

FRANÇA-DANTAS et al. (1987) informaram que em novembro de 1986, foram transferidos do Centro Internacional de Agricultura Tropical (CIAT) para o Centro Nacional de Recursos Genéticos (EMBRAPA-CENARGEN) 326 ecótipos de 14 espécies do gênero Brachiaria, integrantes de uma coleção obtida através de expedição no continente africano, sendo que 286 ecótipos estão sendo caracterizados taxonomicamente e avaliados agronomicamente no Centro de Pesquisa Agropecuária dos Cerrados (CPAC) e serão estudados quanto aos aspectos citogenéticos e reprodutivos no Centro Nacional de Pesquisa de Gado de Corte (CNPGC).

HUMPHREYS (1987) afirmou que o sucesso da introdução de plantas é obtido através do uso de espécies que tenham capacidade de competir no ambiente em questão, seja por luz, umidade ou nutrientes. O mesmo autor explicou que na determinação das características desejáveis a uma planta, vários fatores devem ser considerados, como o ambiente onde a pastagem será estabelecida e o objetivo da exploração pecuária. Em geral, consideram-se aspectos quanto ao valor nutritivo, crescimento e produção de matéria seca, facilidade de estabelecimento e persistência. No entanto, a maioria dos programas de seleção de forrageiras tropicais têm dado maior importância ao rendimento de matéria seca, valor nutritivo e persistência, e dado pouca atenção a características de produção de sementes. Prova disso é que alguns cultivares produzem flores durante um longo período $\mathrm{e}$ as sementes amadurecem desuniformemente, caindo ao solo, com isso as sementes não estão disponiveis para colheita num determinado momento, resultando em escasso suprimento e inevitavelmente preços mais elevados. 
USBERTI FILHO (1992) listou os caracteres que vem sendo ou que devem ser pesquisados para a obtenção de novos cultivares de gramíneas forrageiras tropicais:

a) grande amplitude de adaptação a diferentes condições edafoclimáticas;

b) elevada produção de forragem verde e matéria seca;

c) bom valor nutritivo, principalmente teor de proteína na matéria seca e digestibilidade in vivo e in vitro;

d) tolerância ao pastejo ou ao corte baixo e frequente;

e) tolerância ao pisoteio animal;

f) rebrota rápida e elevado potencial de perfilhamento após pastejo ou corte;

g) alta relação folha/haste;

h) boa aceitabilidade pelos animais (palatabilidade);

i) elevação tardia do meristema apical durante o ciclo vegetativo;

j) decréscimo lento do valor nutritivo com a maturação da planta;

k) viabilidade de consorciação com leguminosas forrageiras;

1) tolerância a solos ácidos e de baixa fertilidade natural;

m) alta eficiência de absorção e utilização de nutrientes presentes no solo;

n) tolerância à seca e ao frio;

o) resistência a pragas e doenças;

p) não provocar distúrbios digestivos e/ou intoxicações nos animais;

q) tolerância ao fogo;

r) tolerância ao encharcamento;

s) boa produção de sementes viáveis.

O autor esclareceu que evidentemente a obtenção de uma planta com todas as características acima citadas é, sem dúvida, muito dificil. Todavia, novos cultivares vêm 
sendo lançados recentemente apresentando grande parte das características desejáveis, abrindo novas opções para os pecuaristas na instalação e/ou renovação de pastagens.

\subsection{Problemas na produção de sementes de gramíneas forrageiras.}

A descrição morfo-agronômica e fenológica de germoplasma vegetal, além de fornecer subsídios necessários à pesquisa, é igualmente importante para os técnicos envolvidos com a produção de sementes de germoplasma, responsáveis pela proteção do patrimônio genético da espécie, além da pureza fisica e varietal das sementes (CARVALHO \& NAKAGAWA, 1980).

Segundo PRIMO (1982) durante séculos as gramíneas forrageiras tropicais foram selecionadas para alta produção de forragem, em detrimento da produção de sementes. Em função disto, o potencial de rendimento de sementes, determinado pelo número e peso das espiguetas, é muito baixo nas cultivares disponíveis.

A grande barreira para o sucesso da produção de sementes de uma nova cultivar é a ignorância. Há apenas alguns anos, uma cultivar era somente um componente obscuro de uma remota flora nativa. A única informação disponível sobre produção de sementes eram observações em canteiros e a experiência obtida através do corte ou pastejo de pequenas parcelas. Em contraste, anos de experiência em campos comerciais de produção de sementes serão necessários antes que a produção de sementes de uma nova cultivar possa ser adequadamente compreendida (HOPKINSON \& EAGLES, 1990). 
Bogdan $^{2}$ citado por BOONMAN (1971) sugeriu que a apomixia, comum em Paniceae e Andropogoneae, está associada a propriedades de baixa produção de sementes.

BOONMAN (1971) informou que diversos ensaios de campo têm levado a algumas afirmações generalizadas para explicar a baixa capacidade de produção de sementes de gramíneas tropicais. Tem-se dito que a maioria das espécies pertencem a tribos que apresentam um baixo potencial para produção de sementes, sendo essas tribos a Paniceae e Andropogoneae. O autor alertou ainda para o fato de que as gramíneas forrageiras tropicais têm sido submetidas a pequena ou nenhuma domesticação visando produção de sementes. Em comparação com cereais isto certamente é correto, no entanto, um número considerável de gramíneas forrageiras temperadas boas produtoras de semente, originaram também da flora silvestre, muitas delas da mesma forma que variedades tropicais. Devemos alertar para o fato de que esse baixo potencial de produção de sementes referido pode ser devido a uma baixa eficiência na colheita das mesmas.

Segundo o mesmo autor, o baixo rendimento e qualidade de sementes de gramíneas tropicais é devido a:

a) prolongado período de emergência de inflorescências na mesma planta;

b) prolongado periodo de florescimento na mesma inflorescência;

c) diminuição do período de florescimento nas inflorescências tardias;

d) baixa formação de sementes (aborto);

e) baixo número de afilhos que produzem inflorescência;

\footnotetext{
${ }^{2}$ BOGDAN, A. V. The selection of tropical ley grasses in Kenya: general considerations and methods
} East African Agricultural and Forestry Journal. Nairobi, 24:206-17, 1959. 
f) ampla variação na emergência de inflorescências entre plantas de uma mesma variedade;

g) outros fatores como baixa retenção de sementes (degrana) doenças nas espiguetas e danos por pássaros.

BOONMAN (1982) afirmou que as gramíneas tropicais apresentam uma baixa eficiência de espiguetas disponíveis, devido principalmente a:

a) espigamento prolongado entre plantas dentro da mesma variedade;

b) emergência prolongada de espigas numa mesma planta, que perdura por vários meses (Figura 1);

c) florescimento prolongado dentro das espigas, continuando por várias semanas (Figura 1);

d) redução no florescimento e na formação de sementes nas espigas de emergência tardia.

De acordo com YADAVA et al. (1984) a produção de sementes de espécies tropicais apresenta muitos problemas que não são encontrados em espécies temperadas, ou que são mais críticos nas tropicais. Estes problemas são devidos a características intrínsecas das espécies e que dificultam a colheita, ocasionando baixos rendimentos de sementes colhidas.

Os mesmos autores afirmaram que cada um dos componentes do rendimento de sementes é afetado de maneira diversa pela composição genética, balanço hormonal, fatores do meio ambiente ou ainda por práticas culturais. No entanto, os maiores problemas e limitações na produção de sementes de gramíneas forrageiras são os seguintes:

a) falta de sincronia no florescimento e maturação das sementes;

b) degrana das sementes maduras; 
c) baixo numero de perfilhos férteis produzidos;

d) baixo rendimento de sementes maduras num determinado momento;

e) baixos índices de colheita.
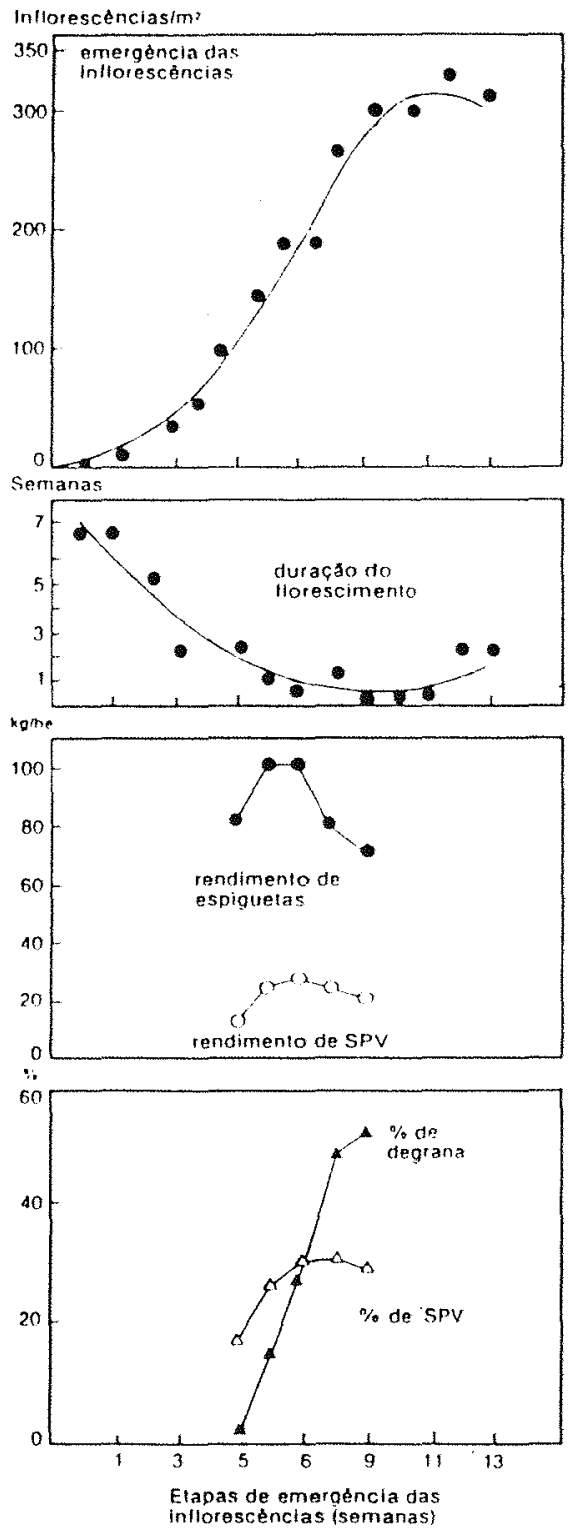

Figura 1. Caracteristicas da produção de sementes de gramíneas tropicais (BOONMAN, 1982). 
PRIMO (1982) citou como fatores limitantes da produção de sementes de gramíneas forrageiras, os seguintes:

a) plantas com florescimento prolongado e maturação desuniforme;

b) populações variáveis;

c) irregularidades reprodutivas.

A eficiência de colheita de sementes de muitas forrageiras tropicais é, de fato, muito baixa, visto que o florescimento se estende durante longo período. Além disso, em muitas espécies as sementes caem no solo logo após a maturação. Desse modo, somente uma pequena proporção da semente produzida pode ser coletada em determinado momento (HUMPHREYS, 1987).

De acordo com Boonman ${ }^{3}$, citado por CROWDER \& CHHEDA (1982) o rendimento de sementes puras germináveis, pode ser incrementado através de práticas agronômicas e de manejo e pelo melhoramento varietal, sem contudo diminuir o rendimento ou o valor nutritivo da forragem. $\mathrm{O}$ autor afirmou ainda que um incremento adicional no rendimento de semente pode ser buscado, em seleções futuras, utilizando-se a variabilidade existente quanto a caracteres como peso da semente, enchimento da semente e número de inflorescências dentro de populações. O aumento na eficiência da colheita do que foi produzido, segundo HOPKINSON \& ENGLISH (1982) também é uma opção para o incremento da rendimento de sementes.

Devemos contudo, estar cientes ao fato de que o indice de multiplicação dessas espécies é alto, visto que a quantidade de semente produzida em determinada área é suficiente para a semeadura de uma área bem maior.

${ }^{3}$ BOONMAN, J. G. On the seed production of tropical grasses in Kenya. Center Agric. Publ. Doc. Wageningen, 1973. 


\subsection{O gênero Brachiaria}

\subsubsection{Origem.}

O leste da África se constitui no principal centro de origem e diversificação de gramíneas do gênero Brachiaria (IBPGR ${ }^{4}$, citado por VALLE \& MILES, 1994).

Segundo GHISI (1991) as gramíneas forrageiras do gênero Brachiaria, comumente chamadas de braquiária, têm distribuição marcadamente tropical, com centro de origem primária na África Equatorial, sendo o Brasil relativamente pobre em representantes nativos deste gênero.

SAVIDAN (1986) afirmou que, ao contrário de outras gramíneas forrageiras tropicais como Andropogon gayamus, Pennisetum purpureum, Hyparhenia rufa e Cenchrus, o gênero Brachiaria e Panicum maximum foram amplamente coletados nos respectivos centros de diversificação, como pode ser observado na Figura 2.

\subsubsection{Importância.}

Segundo SANTOS FILHO (1990) a história das pastagens tropicais no Brasil divide-se em "antes e depois" do aparecimento das sementes de braquiárias.

Grandes quantidades de sementes de $B$. decumbens $\mathrm{cv}$. Basilisk foram importadas da Austrália a partir de 1968, consolidando-se com isso a expansão da pecuária nos cerrados brasileiros (VALLE \& MILES, 1994).

Conforme afirmação de ARONOVICH \& ROCHA (1985) o verdadeiro "ciclo das braquiárias", iniciou-se com a introdução de $B$. decumbens no Instituto de

\footnotetext{
${ }^{4}$ IBPGR - International Board for Plant Genetic Resources. Tropical and subtropical forages. Report of working group. Rome, FAO, 1984. 29p.
} 
Pesquisa Agropecuária do Norte (IPEAN) no estado do Pará, vinda do Suriname. Do Pará, espalhou-se para todo o país, multiplicando-se vegetativamente. Poucos anos depois, foi introduzida a cultivar Basilisk, proveniente da Austrália, a "signal-grass", que se popularizou no Brasil como "australiana", sendo que o gênero Brachiaria constitui-se no grande componente do atual ciclo de pastagens na pecuária brasileira.

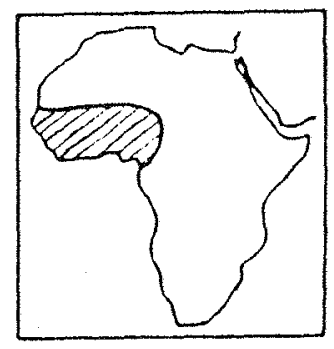

Andropogon

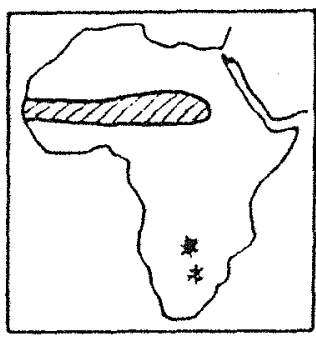

Cenchrus

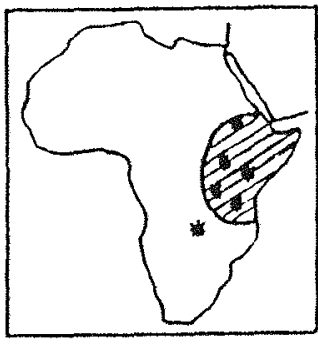

Brachioria

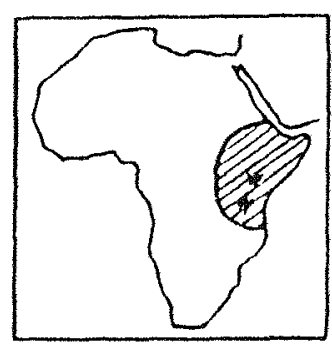

Panicum moximum

Figura 2. Centros de diversificação dos gêneros Andropogon, Brachiaria, Cenchrus e de Panicum maximum, (área hachurada, continente africano). As estrelas indicam as coletas intensivas já realizadas. (Adaptado de SAVIDAN, 1986).

Segundo ALCÂNTARA (1987) a braquiária é conhecida no Brasil desde a década de 50. No entanto, sua grande expansão ocorreu a partir dos anos 70 , com o desbravamento das regiões Centro-Oeste e Norte do país, sendo cultivadas respectivamente as espécies $B$. decumbens e $B$. humidicola. A partir dessas duas 
espécies, foram introduzidas B. ruziziensis, B. brizantha e mais recentemente $B$. brizantha $\mathrm{cv}$. Marandu, que vem predominando na formação e reforma de pastagens, principalmente em substituição ao Panicum maximum $\mathrm{cv}$. Colonião e às pastagens nativas (GHISI, 1991).

O gênero Brachiaria é considerado o principal capim para o cultivo em nosso país, impondo-se em solos anteriormente considerados inaptos até mesmo para o cultivo de pastos, principalmente na região dos Cerrados, sendo considerada uma das mais importantes áreas de exploração pecuária das savanas tropicais do mundo (SANTOS \& AGUIAR, 1985).

Segundo ANDRADE (1994) é incontestável a grande contribuição que o gênero Brachiaria representa para a exploração da pecuária de corte e de leite no Brasil. A expansão de pastagens em solos de baixa fertilidade nos Cerrados brasileiros com espécies deste gênero, principalmente $B$. decumbens, é considerada como a tecnologia que permitiu o desbravamento da região durante a década de $70 . \mathrm{O}$ autor afirmou ainda que a formação de pastagens ampliou a fronteira, não somente para a exploração pecuária, mas também, indiretamente, para a cultura de grãos, pois uma significativa parte das pastagens foi estabelecida após ou em associação ao plantio de arroz de sequeiro.

A contribuição que o gênero Brachiaria vem prestando à pecuária nacional é retratada por PEREIRA (1987) que afirmou que o mesmo colaborou com a desbravação dos Cerrados, aumentando consideravelmente a área com pastos cultivados e ampliando sobremaneira a fronteira para exploração, principalmente da pecuária de corte. Além disso, o gênero contribuiu sensivelmente para o aumento da capacidade de suporte das pastagens, em comparação com a exploração da vegetação nativa, permitindo assim um 
reconhecido aumento do rebanho nacional, não somente no número de cabeças, como também na melhoria de seus indices zootécnicos.

Segundo SOARES FILHO (1994) a braquiária é o capim mais plantado no país, sendo utilizado na cria, recria e engorda dos animais. Essa gramínea vem ocupando áreas de pastagens nativas, que geralmente são de baixa produção em rendimento de forragem e de proteína bruta, ocasionando perda de peso animal na estação seca. O autor prosseguiu, afirmando que o capim braquiária adapta-se às mais variadas condições de solo e clima, ocupando espaço cada vez maior nos Cerrados, com vantagens sobre outras espécies, devido a proporcionar produções satisfatórias de forragem em solos de baixa a média fertilidade.

ZIMMER \& CORREA (1993) destacaram que B. humidicola teve grande destaque na amazônia e $B$. decumbens nas áreas de cerrados, devendo ser esta última, a forrageira tropical com maior área cultivada no mundo, sendo que a mesma adaptou-se perfeitamente às condições de solos ácidos e de baixa fertilidade do cerrado, proporcionando aumentos na taxa de lotação de animais, 5 a 10 vezes maiores que as pastagens nativas destas áreas. O aumento da produção das pastagens e dos rebanhos foi expressivo e possibilitou aos pecuaristas passarem a integrar as atividades de cria, recria e engorda. Os autores informaram ainda que na década de 80 , passaram a ser utilizadas novas forrageiras, B. brizantha cv. Marandu e Andropogon gayamus cv. Planaltina, lançadas pela EMBRAPA, que obtiveram grande aceitação por parte dos produtores.

De acordo com GHISI (1991) a braquiária é atualmente o capim mais cultivado no Brasil, sendo que em São Paulo predomina com mais de 50\% da área de pastagem cultivada, sendo que essa preferência reflete-se em todo o Brasil tropical, principalmente na região Centro-Oeste, o que permite afirmar que o gênero ocupa mais de 37 milhões ha do solo brasileiro. 
De modo geral, segundo SEIFFERT (1980) pode-se atribuir o crescente papel que o gênero Brachiaria vem assumindo nas regiões pecuárias, às seguintes características:

a) altas produções de matéria seca;

b) as principais espécies são estoloníferas;

c) adaptam-se a uma grande gama de tipos de solos;

d) não apresentam problemas limitantes de doenças;

e) seu crescimento é bem distribuído durante a maior parte do ano.

Além da atividade pecuária em si, CONDÉ (1982) ressaltou que a produção de sementes de forrageiras apresenta um grande potencial econômico para o país, por ser esta a forma mais eficiente de estabelecer e recuperar pastagens. Podendo ainda por outro lado, se converter numa importante fonte de divisas, devido à grande demanda nos mercados nacional e internacional.

SOUZA (1991) afirmou que a grande contribuição dada pelas espécies forrageiras do gênero Brachiaria à pecuária nacional, certamente não teria sido a mesma, não fosse a ampla disponibilidade de suas sementes para a formação de áreas de pastagem. Este fato constitui-se em importante mensagem aos técnicos envolvidos na obtenção de novas espécies e variedades de forrageiras para o Brasil, sendo que a contribuição de qualquer introdução para uso comercial, está na dependência direta da ampla disponibilidade de sementes, e qualquer restrição neste sentido poderá impedir uma exploração total das potencialidades do material.

O sucesso e a expansão de áreas de pastagem de braquiária ocorreram, segundo SANTOS FILHO (1990) por dois motivos básicos:
a) adaptação das espécies às condições do Brasil Central;
b) disponibilidade de sementes no mercado. 
Tal atividade desenvolveu-se com tamanha agressividade que o pais, no espaço de 10 anos a partir da década de 70 , passou de importador a principal exportador mundial de sementes desse gênero.

ZIMMER et al. (1994) afirmaram que são comercializadas anualmente no Brasil, mais de 80 mil toneladas de sementes de forrageiras tropicais, sendo $75 \%$ representado por espécies do gênero Brachiaria, indicando que cerca de 60 mil t de sementes de braquiária são comercializadas anualmente e, destes, $60 \%$ e $30 \%$ correspondem respectivamente às espécies $B$. brizantha e $B$. decumbens.

Segundo OLIVEIRA (1994a) 100 mil $t$ de sementes para pastagens são produzidas e consumidas anualmente no mercado interno brasileiro, sendo que este comércio movimenta US\$250 milhões a cada ano, valor equivalente ao mercado do milho híbrido, e onde $80 \%$ do mesmo correspondem a espécies do gênero Brachiaria.

Empresas do Mato Grosso do Sul estão exportando sementes de forrageiras para vários países da América Latina, além dos Estados Unidos, sendo que somente uma empresa fechou contratos em 1993 no valor de US\$500 mil, referentes a exportação de mais de 100 ton de sementes de $B$. brizantha e B. decumbens (OLIVEIRA, 1994b).

As "virtudes" da braquiária são, incontestavelmente, maiores que seus "problemas", e foi com esse espírito e reconhecendo a pobreza de germoplasma disponivel nas Américas, que técnicos do CIAT (Centro Internacional de Agricultura Tropical) financiados pela FAO, através do IBPGR (International Board for Plant Genetic Resources) empreenderam uma ampla expedição de coleta de Brachiaria spp. no leste e sul da África entre 1984-85, onde, com a colaboração do ILCA (International Livestock Centre for Africa) foram percorridos países como Etiópia, Quênia, Tanzânia , Ruanda, Burundi e Zimbabwe, reunindo uma coleção de 824 ecótipos de 24 espécies de Brachiaria (VALLE, 1990). 
Tal coleção, segundo VALLE et al. (1986) não pose ser considerada completa, visto que vários países vizinhos aos percorridos não foram visitados.

Segundo VALLE \& MILES (1994) a importância agronômica e econômica de algumas espécies do gênero Brachiaria para a pecuária tropical, justificam plenamente todo o investimento e esforço de equipes multidisciplinares, em gerar informações sobre esse material.

\subsubsection{Características botânicas}

O gênero Brachiaria compreende cerca de 90 espécies de grande diversidade morfológica e fenológica (Clayton \& Renvoize ${ }^{5}$, citados por VALLE \& MILES, 1994). Pertence à tribo Paniceae, da familia Gramineae e, segundo SENDULSKY (1978) em anos recentes, um grande número de novas espécies africanas têm sido introduzidas no Brasil como forrageiras, no entanto, a identificação taxonômica deste material tem sido completamente negligenciada.

LEITÃO FILHO (1977) descreveu o gênero Brachiaria, como plantas herbáceas, eretas ou prostradas, anuais ou perenes, rizomatosas ou não, comumente emitindo raízes adventícias nos nós em contato com o solo. A bainha foliar é glabra ou pilosa, normalmente excedendo a dimensão dos internós, com lígula branca e hialina, formada por um curto anel membranáceo; lâmina foliar lanceolada, de ápice acuminado, glabra ou pilosa.

\footnotetext{
${ }^{5}$ CLAyTON, W. D. \& RENVOIZE, S. A. Gramineae (Part 3). In: POLHILL, R. M. (ed). Flora of tropical East Africa. Royal Botanical Gardens, Kew, 1982. p.575-600, 898p.
} 
Quanto às caractecterísticas da inflorescência do gênero Brachiaria, há diversas descrições feitas por diversos autores, que utilizaram terminologias distintas para caracteres morfológicos nem sempre concordantes.

Botanicamente, a flor de gramíneas forrageiras é composta por dois flósculos, sendo um masculino e outro hermafrodita, cada um deles dotado de um par de glumas em cuja base se localizam duas outras. Isto significa que a "semente" madura de gramínea forrageira é uma estrutura composta por um fruto seco, indeiscente, denominado "cariopse", involucrado por diversas glumas, sendo que este conjunto recebe o nome de “espigueta" (SOUZA, 1991).

Rosengurtt et al. $^{6}$, citados por SEIFFERT (1980) descreveram a inflorescência de gramíneas forrageiras como sendo uma panícula de espigas de eixo alargado; espigueta mútica, com a gluma I adaxial, antécio II coriáceo, com asperezas punticuladas em finas linhas transversais. Panícula medindo de 11-24cm, com 3-7 espigas com espiguetas solitárias, dispostas em duas fileiras; ráquis com 1,5-3mm de largura, piloso; espigueta obtusa, com 4-4,6mm de comprimento, glabras, gluma II e lema I 5-8 nervadas, sobrepassando quase $1 \mathrm{~mm}$ o antécio, pálea II neutra. Cariopse pouco comprimida dorsiventralmente, com $1,8 \mathrm{~mm}$ de comprimento.

LEITÃO FILHO (1977) descreveu como sendo uma inflorescência paniculiforme ou, no caso mais geral, formada por racemos unilaterais, nos quais se inserem espiguetas sésseis ou pediceladas; ráquis triangular, angulada ou alada, glabra ou ciliada nos bordos; espiguetas solitárias ou aos pares, com a primeira gluma voltada em direção a ráquis da inflorescência (posição adaxial) caráter que identifica prontamente o gênero, segunda gluma e lema estéril com lema encobrindo uma pálea hialina estéril ou

\footnotetext{
${ }^{6}$ ROSENGURTT, B.; MAFFEI, B. A. de; ARTUCIO, P. 1. de. Granineas de ciclo estival: Panaceas. In: 395 Gramíneas uruguayas. Montevideo, Universidade de la Republica, 1970 p.281-
} 
em algumas espécies estaminada; lema e pálea férteis rijas, normalmente papilo-rugosas, com margens levemente revoltas e ápice, em algumas espécies, com curta arista.

Bogdan ${ }^{7}$, citado por VALLE \& MILES (1994) afirmou que gramíneas do gênero Brachiaria apresentam panícula com poucos ( às vezes um só ) a diversos racemos; espiguetas sésseis ou sub-sésseis, arranjadas em duas fileiras em uma ráquis geralmente achatada. Dos dois flósculos da espigueta, o inferior é masculino, com lema e pálea macios e o superior é fértil, bissexual ou muitas vezes feminino, achatado de um lado e convexo do outro. A cariopse está englobada dentro de uma gluma com lema e pálea duras e rígidas.

SEIFFERT (1980) descreveu como sendo uma espiga unilateral ou panícula, com flor hermafrodita ou masculina, com 1-3 estames; espigueta comprimida dorsiventralmente, biflora, com o antécio terminal frutifero e o basal neutro ou masculino, sendo que as glumas caem com o antécio frutífero; glumas menos consistentes que as glumelas (lema e pálea); gluma II e antécio hermafrodita abaxiais e gluma I e antécio neutro adaxiais.

Especificamente, LEITÃO FILHO (1977) descreveu B. brizantha, como possuindo uma inflorescência terminal com $12-16 \mathrm{~cm}$ de comprimento, formada em geral por 4-6 racemos espiciformes alternos, medindo $6-9 \mathrm{~cm}$ de comprimento; ráquis do racemo curto-alada e branco-ciliada nos bordos, com até $1,5 \mathrm{~mm}$ de largura; espiguetas bifloras, unisseriadas, inseridas isolada e alternadamente ao longo da ráquis, curtopediceladas e com articulações engrossadas, medindo 5-6mm de comprimento. Primeira gluma hialina e glabra, com $2 \mathrm{~mm}$ de comprimento, envolvendo a espigueta na base; segunda gluma e lema estéril semelhantes, com lema encobrindo a pálea hialina de uma

\footnotetext{
${ }^{7}$ BOGDAN, A. V. Tropical pasture and fodder plants. Longman, New York, 1977. 455p.
} 
flor estaminada; segunda flor hermafrodita, com lema e pálea rijas, membranáceas, com $4 \mathrm{~mm}$ de comprimento. cariopse rara, brancacenta.

O mesmo autor descreve $B$. decumbens, como apresentando inflorescência terminal com $10-15 \mathrm{~cm}$ de comprimento, formada em geral por $3-5$ racemos espiciformes alternos, medindo $7-12 \mathrm{~cm}$ de comprimento; ráquis do racemo ligeiramente alada, com 1$1,5 \mathrm{~mm}$ de largura e nitidamente branco-ciliada nos bordos; espiguetas bifloras, bisseriadas, inseridas alternadamente ao longo da ráquis, com $5 \mathrm{~mm}$ de comprimento $\mathrm{E}$ com articulações levemente engrossadas. Primeira gluma hialina e glabra, com $2,5 \mathrm{~mm}$ de comprimento, envolvendo a espigueta na base; segunda gluma e lema estéril semelhantes, com 4,5mm de comprimento, pilosas no ápice, com lema envolvendo a pálea hialina da flor estaminada; segunda flor hermafrodita, com lema e pálea com $4 \mathrm{~mm}$ de comprimento, rijas e glabras. Cariopse de ocorrência geralmente comum, brancacenta.

Deve-se atentar para o fato de que as características morfológicas descritas por LEITÃO FILHO (1977) não se referem necessariamente às cultivares B. brizantha cv. Marandu e B. decumbens cv. Basilisk.

Bogdan ${ }^{8}$, citado por STÜR (1986) descreveu a inflorescência madura de $B$. decumbens cv. Basilisk, como uma panícula com 2-5 racemos de comprimentos acina de $5 \mathrm{~cm}$; espiguetas pilosas, com 4-5mm de comprimento, compostas de um flósculo superior hermafrodita e um inferior masculino, arranjadas em duas fileiras numa ráquis de superficie plana.

STÜR (1986) afirmou que em $B$. decumbens, a dimensão da panícula é simples função do número de racemos por inflorescência e do número de espiguetas por racemo, pois há somente um flósculo potencialmente fértil por espigueta.

\footnotetext{
${ }^{8}$ BOGDAN, A. V. Tropical pasture and fodder plants. Longman, New York, 1977. 455p.
} 
Em estudo sobre o desenvolvimento de perfilhos e o florescimento de $B$. decumbens $\mathrm{cv}$. Basilisk, STÜR \& HUMPHREYS (1987) verificaram que o número de racemos por inflorescência, variou de 1 a 4 e apresentavam-se com maior comprimento nas inflorescências emergidas mais precocemente, sendo que o número de espiguetas por racemo apresentou a mesma tendência.

B. brizantha e $B$. decumbens, se reproduzem principalmente via apomixia, onde há reprodução sem fecundação, ocorrendo a formação da semente no óvulo da flor, sem fusão do núcleo da célula-ovo com o núcleo espermático do grão de pólen. Segundo SOUZA (1991) este modo de reprodução é comum em plantas poliplóides, nas quais o processo de meiose durante a formação dos gametas, com frequência apresenta irregularidades, resultando em grande número de flósculos inférteis.

Segundo BOONMAN (1971) a produção de inflorescências em muitas gramíneas tropicais, segue uma curva de padrão sigmóide, com um florescimento prolongado, que engloba uma emissão de anteras e estigmas dentro da inflorescência, que pode estender-se por até quatro meses.

Em geral, a progressão da antese ocorre no sentido basipetal, a taxas bastante lentas, em especial em B. brizantha e $B$. decumbens (SOUZA, 1991).

CANI (1980) verificou que em $B$. decumbens, a prática de cortes ocasionou uma diminuição no número de ramificações por inflorescência. Enquanto que GARCIA et al. (1989) concluíram que a aplicação de nitrogênio aumentou o número destas.

REIS (1981) estudando o efeito de regimes de cortes na produção de sementes de $B$. decumbens, observou que não houve efeito significativo dos mesmos sobre o número de espiguetas por racemo.

Segundo SOUZA (1991) independentemente do número de perfilhos que potencialmente possam emergir em uma cultura, algumas espécies de Brachiaria, 
caracterizam-se por uma enorme precariedade na sincronia da emegência das inflorescências, sendo que em $B$. decumbens, tal fato decorre de variações na época de iniciação floral e na taxa de diferenciação entre perfilhos de mesma idade, tanto que, mesmo em cultura submetida a corte/adubação, citou STÜR \& HUMPHREYS (1985) que coletaram inflorescências "maduras", caracterizadas por apresentarem 10\% de degrana, durante todo um período de 28 dias.

Continuou SOUZA (1991) afirmando que o precário sincronismo de emergência das inflorescências e o prolongado período de antese nas inflorescências individuais, têm reflexos diretos no sincronismo da maturação das sementes, não sendo de surpreender, portanto, que em qualquer momento do ciclo reprodutivo da planta, mesmo na época tida como ideal para colheita mecanizada, seja encontrada toda a gama possível de variação entre flósculos em antese até sementes maduras.

Outra importante caracteristica das espécies do gênero Brachiaria, salientada por SOUZA (1991) é a incapacidade de reter as sementes conectadas às inflorescências, sendo que este fenômeno, chamado degrana natural, resulta do rompimento de uma camada de abscisão que, no caso de Brachiaria spp., bem como das demais espécies pertencentes à tribo Paniceae, forma-se imediatamente abaixo das glumas. Esta ruptura, ocorre após a semente ter alcançado a maturidade ou até mesmo antes, caso ocorram condições de estresse, como por exemplo chuvas excessivas, ventos fortes ou deficiências nutricionais, hídricas ou luminosa.

A interação de diversos aspectos biológicos, caracteriza a produção de sementes de espécies do gênero Brachiaria, como uma atividade de muitos desafios, uma vez que a impossibilidade de manipulação agronômica de alguns componentes importantes desta produção, como a degrana e o período de antese, limita as alternativas de métodos de colheita, diminui a sua eficiência e, consequentemente, a produtividade 
obtida. Devido a isto, a seleção de ecótipos baseada, também, em aspectos relacionados à botânica da reprodução, deve ser aplicada, de forma a garantir resultados mais satisfatórios (SOUZA, 1991).

\subsection{Fenologia reprodutiva e componentes da produção de sementes}

Fenologia é, segundo o dicionário Webster's, a forma condensada da palavra fenomenologia. Segundo RATHCKE \& LACEY (1985) é o estudo do ritmo estacional dos eventos do ciclo de vida das plantas ou animais.

FONT QUER (1989) de forma mais especifica, definiu a mesma como o estudo dos fenômenos biológicos, dispostos em certo ritmo periódico, como a brotação, o florescimento e a maturação dos frutos. Como são naturais, esses fenômenos se relacionam com o clima da região onde ocorrem. Etimologicamente, é o estudo dos aspectos que se sucedem no ciclo de vida de uma espécie. A fenologia de uma espécie depende de sua própria idiossincrasia, ou seja, da maneira como a mesma reage a fatores externos, e do "ciclo energético" do meio, sobretudo e mais geralmente do ciclo climático.

O estudo da fenologia de gramíneas é básico, seja para a compreensão das suas respostas funcionais às condições de ambiente, seja para efetuar o manejo das diferentes espécies, visando sua manutenção, incremento ou eventual eliminação (ALMEIDA, 1995).

A fenologia reprodutiva, bem como alguns componentes da produção de sementes, são influenciados pelas condições do ambiente sob o qual se encontram. Desse 
modo, os requerimentos climáticos relacionados com a produção de sementes serão abordados a seguir.

\subsubsection{Requerimentos climáticos}

HUMPHREYS (1979) afirmou que a condição climática nas quais uma cultura se desenvolve é fator fundamental como determinante do rendimento de sementes e, com exceção do suprimento de água e nutrientes, pode ser apenas parcialmente modificado pelo produtor, sendo que o clima ideal para produção de sementes deve apresentar radiação solar adequada, temperatura e precipitação pluvial suficientes para o desenvolvimento vegetativo, fotoperíodos favoráveis à indução floral e, ainda, deve ser seco, com ventos relativamente fracos, durante a maturação das sementes. Segundo o mesmo autor, muitas plantas forrageiras tropicais estão, durante a maior parte do ano, sob condições climáticas que induzem ao florescimento. Elas podem apresentar respostas quantitativas no florescimento, devido a alguma variação climática, mas produzirão flores sempre que os ramos forem suficientemente grandes e maduros.

A produção de sementes pelas espécies do gênero Brachiaria, reflete o efeito do periodo prolongado de antese nas inflorescências individuais. Clima chuvoso, com baixa luminosidade, baixas temperaturas e/ou ventos fortes, interferem no processo de antese, prolongando-o (SOUZA, 1991).

Acerca do efeito do fotoperiodo, HUMPHREYS (1979) afirmou que para muitas cultivares, o comprimento do dia, ou mais exatamente, a duração do período noturno, determina quando ocorrerá o florescimento ou a intensidade da resposta ao mesmo. O fotoperíodo é, ainda, de grande significância ecológica visto que em variedades adaptadas a determinado ambiente, ele impede um bom florescimento em 
condições climáticas desfavoráveis e facilita a fecundação cruzada, sincronizando o florescimento de plantas vizinhas.

HUMPHREYS (1979) afirmou que nas regiões tropicais e subtropicais, as plantas são geralmente de dias curtos, dias médios ou neutras.

Através de observações de campo, realizadas no Centro de Pesquisa Agropecuária dos Cerrados, ANDRADE \& THOMAS (1983) verificaram que $B$. decumbens produz inflorescências durante um longo período, apresentando variação na maturação de sementes, dentro e entre inflorescências, sendo a espécie considerada neutra quanto à ação do fotoperíodo.

Os requerimentos fotoperiódicos à floração de algumas espécies mais importantes de Brachiaria, como B. brizantha e $B$. decumbens, não estão todavia elucidados, não havendo informações suficientes para classificá-las de modo definitivo dentro de nenhum dos grupos de requerimentos fotoperiódicos. No entanto na prática, tem-se observado que, quando cultivadas dentro da região delimitada aproximadamente pelas latitudes $15^{\circ}$ e $23^{\circ} \mathrm{S}$, que compreende o "Brasil Central Agropecuário", $B$. brizantha e $B$. decumbens apresentam dois picos de florescimento por ano, florescendo em fevereiro/junho para as duas espécies no primeiro ano e nos anos subsequentes em janeiro/abril e dezembro/março, respectivamente para as duas espécies, podendo ainda variar em função da localização geográfica da área de produção e das práticas agronômicas de manejo adotadas (SOUZA, 1991).

De acordo com HUMPHREYS (1979) diversos experimentos de campo são efetuados sob condições onde os componentes climáticos não podem ser separados, sendo que o efeito de um ou outro fator não pode ser detectado, assim se diz que a flor (espigueta) de gramíneas forrageiras, permanecem completamente fechadas em dias úmidos, frios e nublados. 
HESKETH (1963) afirmou que gramíneas tropicais, sendo plantas de ciclo $\mathrm{C}_{4}$, têm maior capacidade de crescimento que temperadas, devido a maior resposta a níveis elevados de radiação, resultando disto que plantas cultivadas em regiões recebendo alta radiação, têm um maior potencial para produção de sementes, salientando-se que o rendimento de sementes depende de uma alta taxa de crescimento vegetativo inicial, que determina o número de flores, bem como de uma contínua atividade fotossintética durante o processo de enchimento do grão.

A velocidade de desenvolvimento da inflorescência aumenta em dias moderadamente quentes e a formação de sementes em plantas tropicais é negativamente afetada por baixas temperaturas. O ritmo diurno de florescimento é dependente da temperatura, sendo que o tempo em que espiguetas individuais permanecem abertas, com anteras completamente salientes e sem, no entanto, se romper, é importante para os melhoristas de plantas, sendo esta situação máxima em baixas temperaturas. Ondas de calor também reduzem a fertilidade do grão de pólen, sendo que a germinação do mesmo requer temperaturas ótimas em função da espécie (HUMPHREYS, 1979).

Com relação à umidade relativa do ar, ainda HUMPHREYS (1979) relatou que altos níveis são importantes para a polinização de diversas espécies tropicais, sendo a germinação do grão de pólen reduzida, abaixo de determinada porcentagem de umidade relativa do ar. $\mathrm{O}$ autor esclarece também, que a umidade relativa do ar relaciona-se negativamente com o índice de deiscência nas leguminosas, o que nos faz supor que o mesmo deva ocorrer com a degrana das gramíneas.

Concluíndo, HUMPHREYS (1979) alertou para a necessidade de, primeiramente, haver uma compreensão mais exata sobre o modo como o clima influencia os processos de produção de sementes, antes que se possa determinar a região mais eficiente para o mesmo, além do manejo adequado da cultura, como a determinação da 
época e espaçamento de semeadura, avaliação do risco de aplicação de fertilizantes, estratégia de irrigação, prática de desfolhamento e procedimentos de colheita.

\subsubsection{Fenologia reprodutiva}

O estudo do ciclo de vida de uma planta divide-se em fenologia vegetativa, que compreende desde a semeadura ou plantio até a iniciação floral, e daí a fenologia reprodutiva que se estende até a maturação das sementes.

No início do desenvolvimento de algumas espécies, existe uma fase de juvenilidade que foi definido, segundo TING (1982), como um estágio de grande crescimento dos tecidos, acompanhado por altas taxas de respiração, metabolismo de ácido nucléico e síntese de proteína, sendo que esta fase varia em duração e época, dependendo da espécie em questão. Após esta, os tecidos estão maduros e os eventos metabólicos e fisiológicos são mais lentos e uniformes.

Diversas plantas necessitam passar por uma fase juvenil, antes de estarem receptivas a um estímulo floral, sendo esse estádio de "maturidade para florescer", frequentemente relatado simplesmente em função do tamanho da planta ou do número mínimo de folhas, que indica a acumulação suficiente de metabólitos (HUMPHREYS, 1979).

TING (1982) afirmou que a transição entre a fase de crescimento vegetativo para reprodutivo ocorre em resposta a "sinais" do meio ambiente. Desde que a planta apresente desenvolvimento e maturidade suficientes e dependendo da espécie, o fotoperiodo, a temperatura ou o regime hídrico podem agir como estímulos ambientais, assinalando a passagem da fase vegetativa para a reprodutiva. 
ANDRADE \& THOMAS (1983) observaram que $B$. decumbens cv. Basilisk apresentou a primeira floração em $20 / \mathrm{fev}$. no primeiro ano e em 10/dez. nos anos seguintes, apresentando um adiantamento de 52 dias a partir do segundo ano.

Observou-se que $B$. brizantha e $B$. decumbens apresentam, via de regra, dois ou ocasionalmente, três picos de florescimento ou florada, dos quais o terceiro é de pouca importância para a produção de sementes e que, normalmente, é menor o número de floradas em culturas de primeiro ano, indicando talvez, a existência de um periodo de juvenilidade nestas espécies (SOUZA, 1991).

STÜR (1986) alertou para a necessidade do conhecimento sobre o desenvolvimento do meristema apical durante o crescimento vegetativo, iniciação floral e desenvolvimento de inflorescências de gramíneas tropicais, de modo a facilitar o manejo das culturas e auxiliar na análise de experimentos de produção de sementes. No entanto, o autor considera esse conhecimento ainda bastante escasso.

Baseado na morfologia do meristema apical de B. decumbens, STÜR (1986) dividiu o desenvolvimento de perfilhos em seis fases, a saber:

1) vegetativa;

2) iniciação do racemo;

3) iniciação da espigueta;

4) diferenciação da espigueta;

5) emissão da inflorescência e antese;

6) maturação da semente.

$\mathrm{Na}$ intensão de correlacionar o estádio de desenvolvimento de um perfilho, com parâmetros morfológicos do mesmo, STÜR (1986) apresentou uma descrição de todas as fases do desenvolvimento, desde o crescimento vegetativo até a formação das 
espiguetas, e concluiu, afirmando que estas fases podem ser, razoavelmente descritas, através do comprimento e peso seco do perfilho e do alongamento do internó.

STÜR \& HUMPHREYS (1988), estudando o desenvolvimento dos perfilhos e o florescimento em $B$. decumbens $\mathrm{cv}$. Basilisk, verificaram que a iniciação do racemo ocorreu 10-15 dias após a emergência do perfilho, sendo a transição entre a fase vegetativa e a reprodutiva bastante breve e raramente identificada. Nos perfilhos emergidos cinco dias após à queima das parcelas, a iniciação do racemo, da espigueta, a diferenciação das espiguetas e a emissão da inflorescência, ocorreram respectivamente, $14,21,26$ e 59 dias após a emissão do perfilho, sendo ainda que o periodo de emissão de inflorescências variou em até 30 dias nestes mesmos perfilhos. Verifica-se que, segundo o autor, o período compreendido entre a diferenciação do racemo e a emissão da inflorescência foi de 45 dias.

\subsubsection{Componentes da produção de sementes}

HUMPHREYS (1979) afirmou que o rendimento final obtido pelo produtor de sementes, depende do modo como vários fatores influenciaram na sequência completa dos processos de desenvolvimento da cultura, bem como da sincronia desses processos, a fim de fornecer uma grande quantidade de sementes disponiveis para colheita em um determinado momento. Afirmou ainda que, para diversas forrageiras, o rendimento de sementes viáveis, por unidade de área, que é finalmente embalada para venda ou uso, é o produto final dos seguintes parâmetros:

a) número de perfilhos por unidade de área;

b) porcentagem desses perfilhos que sobrevivem até a época de florescimento; 
c) porcentagem de perfilhos sobreviventes que são férteis;

d) número de ramificações por inflorescência;

e) número de flores diferenciadas (espiguetas) por ramificação;

f) número de sementes formadas por flor;

g) peso individual da semente;

h) porcentagem de semente efetivamente coletada;

i) porcentagem de semente coletada que é viável.

$\mathrm{O}$ rendimento potencial de sementes de gramíneas forrageiras é determinado antes que o produtor realmente veja a inflorescência emergindo da bainha da folha (HUMPHREYS, 1987).

O início de desenvolvimento reprodutivo é caracterizado pelo aumento no comprimento do meristema apical, prosseguindo com a expansão de uma gema situada na axila do último primórdio foliar formado, sendo que esta gema origina o primeiro racemo e os demais são formados em sucessão basipetal (STÜR, 1986). O mesmo autor, através de observações, relatou que possivelmente o número total de racemos já é determinado aproximadamente quatro dias após o começo da iniciação da espigueta, devido a não se ter verificado novos racemos iniciados após este período, sendo que da mesma forma, o número potencial de espiguetas, parece ser determinado aproximadamente cinco dias após o início de diferenciação das mesmas.

De acordo com CROWDER \& CHHEDA (1982) apesar de gramíneas tropicais e temperadas possuirem componentes de rendimento similares, os atuais rendimentos de sementes puras das cultivares tropicais disponíveis, geralmente não passam de $15-20 \%$ do potencial, sendo muito menor ainda em termos de sementes puras viáveis, se comparado com cultivares temperadas. Os autores afirmaram ainda que, baixa densidade de inflorescências, baixa formação de sementes, baixa sincronia dos 
componentes de rendimento, aliados ao manejo inadequado da cultura, parecem ser as causas primárias do baixo rendimento de sementes de gramíneas tropicais.

SOUZA (1986) afirmou que diversas práticas de manejo podem resultar em maiores produtividades de sementes, não apenas pela interferência direta sobre o processo de desenvolvimento das plantas e sementes, mas também pelo aumento da eficiência de colheita, uma vez que as mesmas podem adequar a cultura aos meios, métodos e equipamentos a serem empregados. $\mathrm{O}$ autor afirmou ainda que eventuais aumentos de produtividade, em função de cortes são decorrentes, entre outros, de:

a) aumento no número de perfilhos reprodutivos;

b) maior sincronismo no desenvolvimento das plantas e consequentemente, maior homogeneidade na maturação das sementes;

c) redução no volume e altura das plantas, que conduz a maior eficiência na utilização de equipamentos mecânicos;

d) extensão do período de colheita, que ocasiona redução dos riscos causados por variações climáticas e utilização sobrecarregada de equipamentos;

e) obtenção de subprodutos (forragem);

f) redução dos riscos de acamamento.

Além do manejo através de corte e/ou pastejo, o autor afirmou que o preparo do solo, controle de ervas daninhas e adubação, influenciam diretamente a produtividade de sementes.

CANI (1980) estudando a influência do nitrogênio, de cortes e de épocas de colheita, sobre a produção e qualidade de sementes de $B$. decumbens, observou que os cortes aumentaram a densidade de inflorescências e a produção de sementes puras. $\mathrm{O}$ mesmo foi observado por GARCIA et al. (1989) através da aplicação de nitrogênio. 
Estudando a época de colheita sobre a produção e qualidade de sementes de B. brizantha em Botucatu, SP, NAKAGAWA et al. (1991) verificaram que as maiores quantidades de sementes germináveis foram obtidas nas colheitas realizadas em 17 a 28 março e em 25 abril a 5 maio. Enquanto que CASTRO (1992) concluiu que em Auriflama, SP, a melhor época para colheita de sementes de $B$. decumbens pelo método de varredura foi maio, e pelo método de corte foi aos 30 dias após o início de emergência das inflorescências.

\subsection{Qualidade de sementes}

A análise de sementes, sejam em trabalhos de pesquisa ou de melhoramento genético, devem ser realizadas sistematicamente, visando verificar e avaliar a qualidade das mesmas. Dessa maneira, baseado nos resultados de testes, pode-se chegar a conclusões importantes, permitindo recomendações úteis aos tecnologistas de sementes, bem como servir de subsídio para a aprovação ou rejeição de novos cultivares que sejam de interesse comercial (MARCOS FILHO et al., 1987).

HUMPHREYS (1987) definiu qualidade de semente, primeiro pela proporção de sementes que germinam para formar plântulas sadias e, segundo, por estarem livres de contaminação por sementes de diferente constituição genética, por material inerte ou por insetos e patógenos, alertando também que, contaminação com sementes de desempenho inferior, pode prejudicar o trabalho realizado no melhoramento da cultura, sendo que considerações como longevidade no armazenamento, taxa de germinação, vigor, dormência, origem e tamanho também devem estar envolvidos na qualidade da mesma. 
O Brasil Central caracteriza-se por apresentar precipitação pluvial anual elevada (acima de $1000 \mathrm{~mm}$ ) e não raramente, a fase de maturação de pelo menos parte das sementes de espécies de Brachiaria, coincide com períodos de pouca luminosidade e alta umidade relativa do ar, o que pode favorecer o aparecimento de doenças, influenciando na qualidade das sementes produzidas (SOUZA, 1991).

Segundo MARCOS FILHO et al. (1987) a germinação, em tecnologia de sementes, é definida como a emergência e o desenvolvimento das estruturas essenciais do embrião, manifestando sua capacidade para dar origem a uma plântula normal, sob condições ambientais favoráveis.

Uma propriedade característica da maioria das espécies do gênero Brachiaria é a dormência das sementes, definida por HUMPHREYS (1987) como um fenômeno natural de proteção, que impede que todas as sementes de uma população germinem numa mesma ocasião, prevenindo a perda de todas as reservas das sementes após as primeiras chuvas, uma vez que condições adversas, como seca, extremos de temperatura, pragas e doenças, podem ocasionar a morte das plântulas germinadas. Portanto, a dormência é uma medida de segurança que beneficia a espécie, mas no caso de avaliação da qualidade através de teste de germinação, requer alguns tratamentos especiais para superá-la.

O mesmo autor explicou que a dormência depende de diversos fatores e, excluindo-se as sementes que não germinam devido a terem sido colhidas antes que os embriões tivessem completado seu desenvolvimento normal, podemos identificar dois tipos de dormência: primeiro há o embrião dormente, que está fisiologicamente inativo devido a inatividade do sistema enzimático e, segundo, há a dormência relacionada com as características das camadas que recobrem a semente. 
$\mathrm{Na}$ germinação de sementes de Brachiaria spp., assim como de outras gramíneas forrageiras tropicais, existem sérios problemas relacionados com o grau de maturação e ocorrência de dormência nas mesmas, sendo que sementes recém-colhidas destas espécies, não germinam, mesmo quando expostas à condições adequadas de temperatura e umidade para o crescimento e desenvolvimento das plântulas. A dormência, seja qual for a sua origem, é geneticamente controlada e fisiologicamente complexa, causando problemas na análise da qualidade e comercialização destas sementes (HOPKINSON \& EAGLES, 1990).

A germinação de sementes de $B$. decumbens, segundo WHITEMAN \& MENDRA (1982) mostrou ser controlada por dois mecanismos de dormência, sendo um de ordem fisiológica, manifestado de forma variável em sementes recém colhidas e que é superado durante um período de armazenamento em torno de 3 meses e, outro prolongado, provavelmente devido à restrição mecânica do tegumento à difusão de oxigênio.

Segundo MARCOS FILHO et al. (1987) o teste de tetrazólio é um método rápido, que estima a viabilidade das sementes, baseado na alteração da coloração de tecidos vivos em presença de uma solução de sal de tetrazólio, sendo que essa modificação na coloração, resultante da atividade de sistemas enzimáticos específicos, está intimamente relacionada com a viabilidade das sementes. De acordo com os mesmos autores, o analista, examinando as diferenças de coloração, a localização e a natureza dos distúrbios, pode obter uma rápida estimativa da viabilidade ou vitalidade do embrião da semente. A viabilidade indica que a semente pode germinar se colocada em condições favoráveis de ambiente. No entanto, a semente viva porém dormente não é identificada pelo teste, podendo apresentar viabilidade, ou seja, o embrião vivo (colorido) mas não vitalidade, ou seja, capacidade de germinar, naquela determinada data. 
Souza' ${ }^{9}$, citado por CASTRO (1992), afirmou que o sucesso da utilização do teste de tetrazólio em sementes de Brachiaria spp., dentre outras espécies de gramíneas forrageiras, baseia-se no treinamento específico e na habilidade do analista em executá-lo, principalmente em função das características morfológicas destas sementes.

${ }^{9}$ SOUZA, F. H. D. de. Problemas de análise de sementes de forrageiras. In: SEMANA DE ANÁLISE DE SEMENTES. Piracicaba, 1991. Palestra proferida. Piracicaba, FEALQ, 1991.19p. 


\section{MATERIAL E MÉTODOS}

\subsection{Ecótipos e cultivares}

Os ecótipos de Brachiaria brizantha (Hochst. ex A. Rich.) Stapf e Brachiaria decumbens Stapf são provenientes de uma coleção, resultante de expedições de coleta no leste da África, entre 1984 e 1985.

O germoplasma caracterizado encontra-se identificado na Tabela 1.

Tabela 1. Germoplasma caracterizado.

\begin{tabular}{|lc|}
\hline \multicolumn{1}{|c|}{ ESPECIE } & $\begin{array}{c}\text { IDENTIFICAÇÃO SNPA * } \\
\text { (BRA) }\end{array}$ \\
\hline Brachiaria brizantha & 002801 \\
B. brizantha & 003361 \\
B. brizantha & 003441 \\
B. brizantha & 003484 \\
B. brizantha & 003891 \\
B. brizantha & 004308 \\
B. decumbens & 004391 \\
B. brizantha cv. Marandu & \\
B. decumbens cv. Basilisk & \\
\hline
\end{tabular}

* SNPA = Sistema Nacional de Pesquisa Agropecuária 
A seleção dos ecótipos foi baseada em resultados experimentais obtidos na EMBRAPA - Centro de Pesquisa Agropecuária dos Cerrados (Planaltina-DF) e Centro Nacional de Pesquisa de Gado de Corte (Campo Grande-MS) e no CIAT (Colômbia) onde foram avaliados segundo metodologia proposta por TOLEDO (1982).

\subsection{Localização e instalação do experimento}

O experimento foi realizado em área do Departamento de Agricultura da Escola Superior de Agricultura "Luiz de Queiroz" (ESALQ/USP), em Piracicaba, SP $\left(22^{\circ} 42^{\prime} 30^{\prime \prime} \mathrm{S}, 47^{\circ} 38^{\prime} 00^{\prime \prime} \mathrm{O}, 540 \mathrm{msnm}\right)$.

O solo apresentava as seguintes características:

- Classificação: Terra Roxa Estruturada (TE)

- Granulometria: - argila: $47 \%$

- areia: $35 \%$

- silte: $18 \%$

- $\mathrm{pH}\left(\mathrm{CaCl}_{2}\right): 5,5$

- Fósforo: 0,31 emg $\mathrm{P}_{2} \mathrm{O}_{5} / 100 \mathrm{ml}$

- Potássio: 0,30 emg $\mathrm{K}_{2} \mathrm{O} / 100 \mathrm{ml}$

- Cálcio + Magnésio: 6,90 emg Ca+Mg/100ml

- Hidrogênio + Alumínio: 2,55 emg H+Al/100ml

- Saturação de bases (V): $75 \%$

- Capacidade de troca catiônica (CTC): $8,8 \mathrm{emg} / 100 \mathrm{ml}$ 
A adubação de plantio constou de $225 \mathrm{~kg} / \mathrm{ha}$ de Superfosfato Simples (45 $\mathrm{kgP}_{2} \mathrm{O}_{5} / \mathrm{ha}$ ) incorporado antes da semeadura e $100 \mathrm{~kg} / \mathrm{ha}$ de Sulfato de Amônio (20 kgN/ha ) em cobertura.

A área da parcela, representando cada ecótipo, foi de $2 \times 14 \mathrm{~m}\left(28 \mathrm{~m}^{2}\right)$ com 4 linhas, sendo a área útil de $1 \times 13 \mathrm{~m}$ com 2 linhas.

A semeadura foi realizada em 05/11/92, manualmente, com espaçamento de $0,5 \mathrm{~m}$ entre linhas e $2,0 \mathrm{~m}$ entre parcelas. A taxa da semeadura foi de $2,0 \mathrm{~kg} / \mathrm{ha}$ de SPG (sementes puras germináveis, $\mathrm{VC}=100 \%$ ) sendo que o valor cultural $(\mathrm{VC}$ ) foi obtido através de testes de pureza e de germinação, realizados previamente com as sementes recebidas.

O experimento foi estabelecido em blocos ao acaso, com 4 repetições.

\subsection{Coleta de dados}

No primeiro ano, foi registrada a data de início de emissão de inflorescências de cada ecótipo, considerada quando da emergência de 5-10 inflorescências $/ \mathrm{m}^{2}$, segundo BOONMAN (1971).

No segundo ano, foi realizado um corte de uniformização ao final da estação seca (14/out/93) a $15 \mathrm{~cm}$ de altura, com remoção da palhada, após o qual iniciaram-se as observações, a saber:

\subsubsection{Fenologia reprodutiva}

No estudo da fenologia reprodutiva, foram determinados:

a) inicio de emissão de inflorescências; 
b) pleno florescimento;

c) início de degrana;

d) fim de degrana.

Primeiramente foram registradas as datas de:

a) início de emissão de inflorescências (IEI);

b) pleno florescimento (PF), considerado quando da existência de mais de 510 inflorescências em antese $/ \mathrm{m}^{2}$.

Tais observações foram realizadas na área útil das parcelas.

No pleno florescimento, foi instalado ao acaso, um coletor de sementes na área útil de cada parcela e foram inseridas 5 inflorescências em antese e sem degrana no mesmo. Detalhes do coletor de sementes e o esquema de instalação do mesmo no campo, são apresentados nas Figuras 3 e 4, respectivamente.

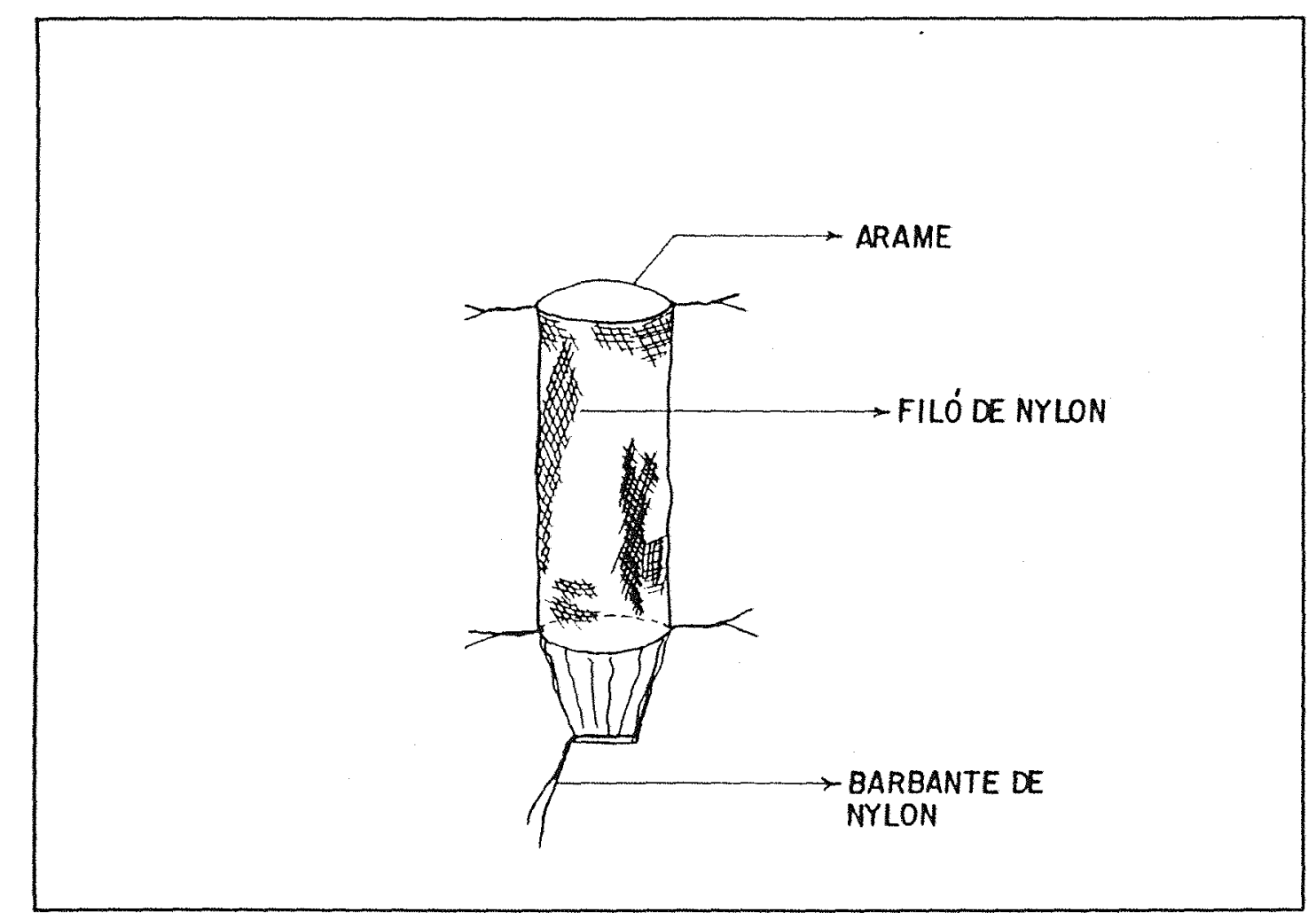

Figura 3. Coletor de sementes. 


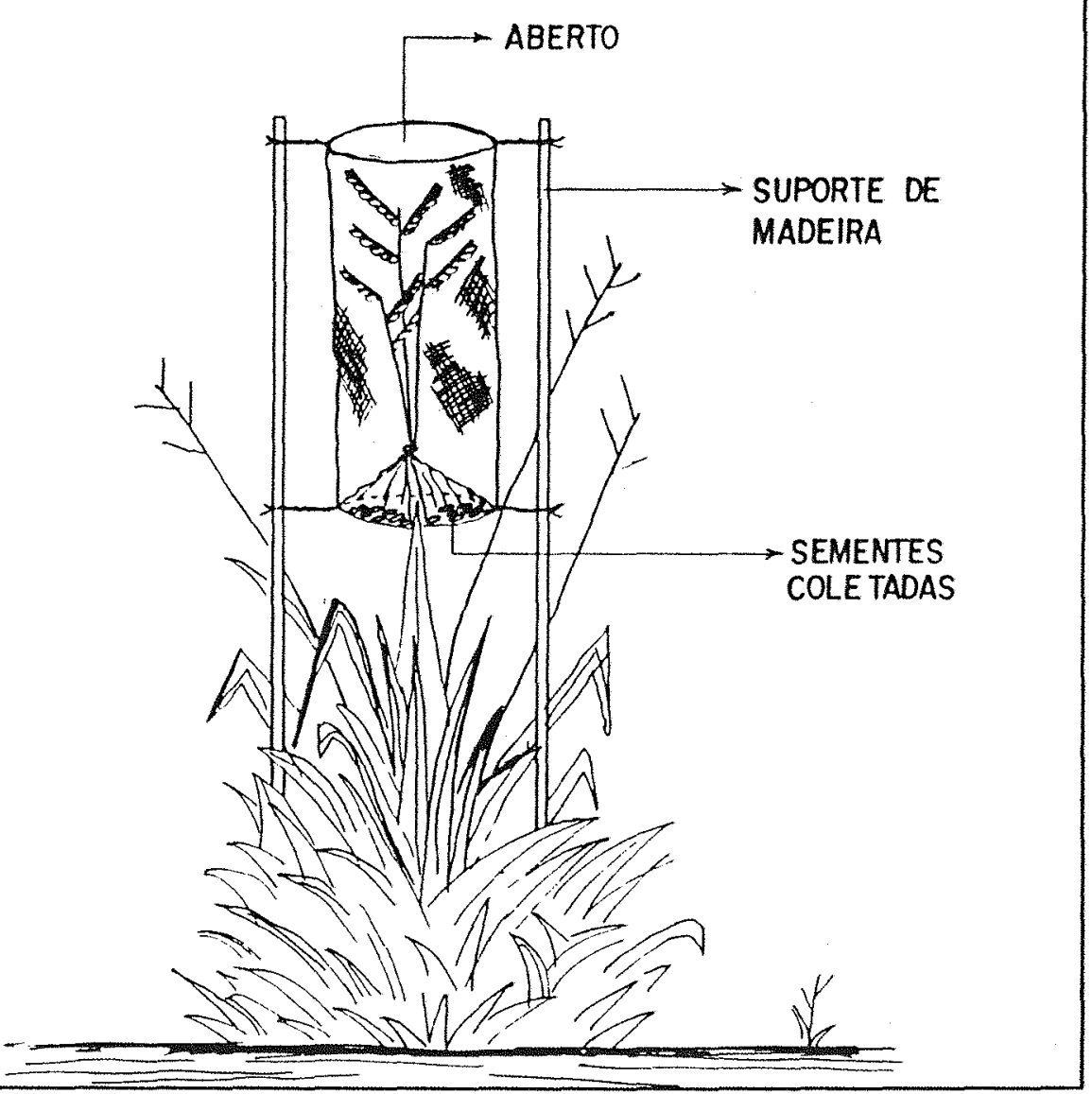

Figura 4. Esquema ilustrativo de instalação do coletor de sementes no campo.

Baseado nas inflorescências do coletor, foram registradas as datas de:

c) início de degrana (ID), considerado quando da existência de espigueta na base do coletor.

d) fim de degrana (FD), considerado quando da inexistência de espigueta presa à ráquis das inflorescências.

A taxa de degrana diária foi calculada através da fórmula:

$100 /$ [número de dias da fenofase (ID-FD)] 


\subsubsection{Caracterização morfológica das inflorescências}

$\mathrm{Na}$ caracterização morfológica das inflorescências, foi determinado:

a) número de racemos por inflorescência;

b) amplitude de variação do número de racemos por inflorescência;

c) número de espiguetas por racemo;

d) comprimento dos racemos;

e) comprimento da inflorescência;

f) tipo de fila de espiguetas.

Quando do pleno florescimento, foi registrada a variação quanto ao número de racemos por inflorescência (NR) determinando-se, através de amostragem de 10 inflorescências por parcela, o número majoritário (moda), sendo então tais inflorescências consideradas como típicas do ecótipo.

Foram coletadas 8 inflorescências típicas, sendo 2 por repetição e determinados os caracteres $\mathrm{c}, \mathrm{d}, \mathrm{e}, \mathrm{f}$, supra citados.

$\mathrm{Na}$ determinação do número de espiguetas por racemo (NE) as espiguetas pouco desenvolvidas e com tamanho inferior a um terço do tamanho da maioria, não foram consideradas, sendo denominadas "primórdios de espiguetas" (PRI) como ilustra a Figura 5. A contagem foi efetuada em cada racemo, sendo que a numeração dos racemos é crescente da base ao ápice da inflorescência, como mostra a Figura 6,a.

O comprimento do racemo (CR) foi determinado para cada racemo da inflorescência, sendo considerado desde o eixo da inflorescência até o ápice do racemo, como ilustra a Figura 6,b.

No comprimento da inflorescência $(\mathrm{CI})$ considerou-se a distância entre as bases do primeiro e último racemos, como mostra a Figura 6,c. 


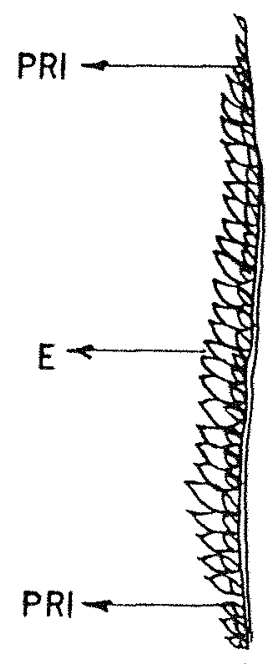

Figura 5. Vista lateral do racemo, com espiguetas (E) e primórdios de espiguetas (PRI).

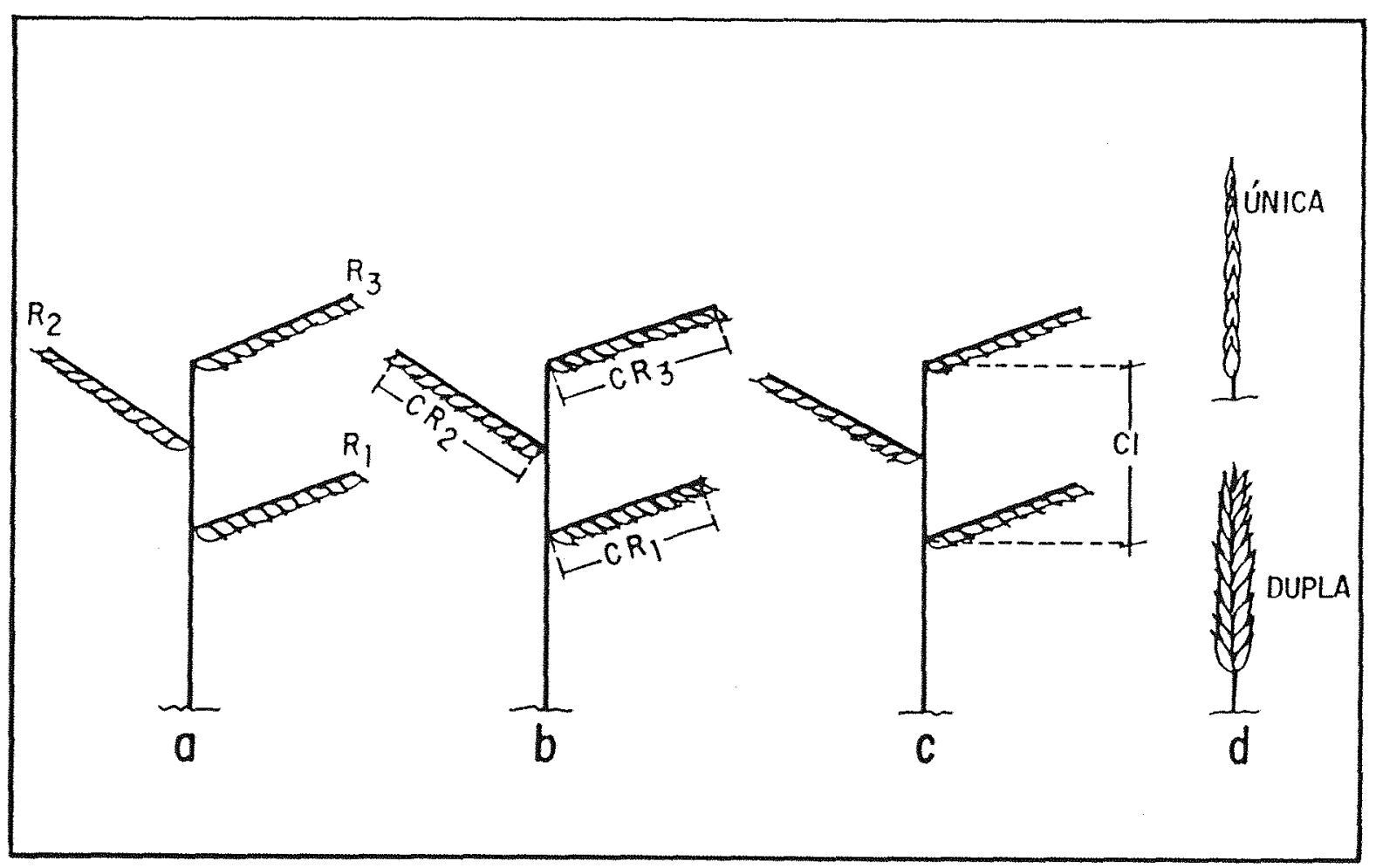

Figura 6. Referenciais para caracterização das inflorescências. 
O tipo de fila de espiguetas compreende a forma de inserção das mesmas no racemo, formando fila única ou dupla, como ilustra a Figura 6,d. Foi considerado o tipo predominante nas inflorescências, uma vez que alguns ecótipos apresentavam fila dupla na porção basal - aproximadamente $1 / 3$ do comprimento do racemo - e única na porção restante.

\subsubsection{Componentes da produção de sementes}

Após a degrana total das sementes no coletor, o mesmo foi retirado com as inflorescências e sementes degranadas e levado ao laboratório onde foram determinados os seguintes parâmetros, por coletor:
a) sementes puras;
b) espiguetas chochas;
c) primórdios de espiguetas;
d) número total de pedicelos;
e) peso de 100 sementes e número de sementes por grama.

No laboratório, o material degranado foi retirado do coletor, separado das inflorescências secas - eixo e ráquis - e estratificado, através de um soprador modelo South Dakota, com abertura 26 simples, durante 3 minutos. A porção mais pesada, constituída pelas cariopses, foi ainda pressionada individualmente com uma pinça, para deteç̧ão de espiguetas chochas que porventura estivessem presentes. O material elevado (mais leve) foi examinado, onde constatou-se a ausência de sementes puras.

Após a separação, foram contadas as sementes puras (SP) e as espiguetas chochas (EC). 
Nas inflorescências secas, a face ventral da ráquis foi analisada, através de lupa de mesa e lupa estereoscópica, sendo anotado o número total de pedicelos (NTP) por inflorescência, considerando-se os pedicelos de espiguetas (PE) e os pedicelos de primórdios de espiguetas (PPRI) como demonstrado na Figura 7.

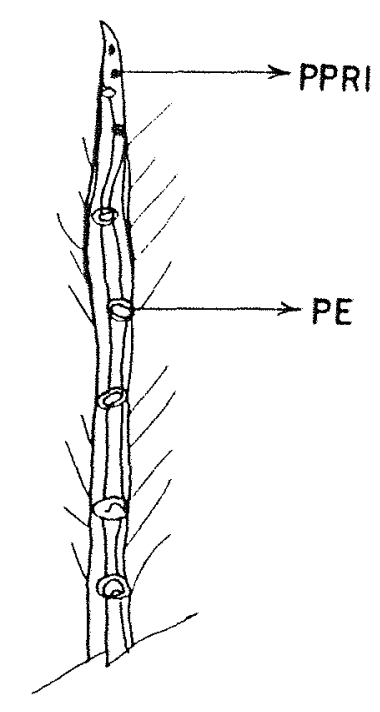

Figura 7. Vista ventral de parte da ráquis após degrana, com pedicelos de espiguetas (PE) e pedicelos de primórdios de espiguetas (PPRI).

$\mathrm{O}$ número de primórdios de espiguetas (PRI) foi obtido através do número total de pedicelos (NTP) subtraído do número de SP e de EC.

$\mathrm{O}$ peso das sementes foi determinado, utilizando-se as sementes puras coletadas, através de balança analítica, com aproximação de $0,1 \mathrm{mg}$. O número de sementes por grama foi obtido através de cálculo estequiométrico (regra de três).

A taxa de aborto $(\mathrm{AB})$, sendo o inverso da taxa de "vingamento" foi considerada como sendo a porcentagem de espiguetas chochas, em função do total de 
espiguetas efetivamente formadas, desconsiderando-se os primórdios de espiguetas (PRI), sendo calculada através da fórmula:

$\mathrm{AB}=$ (número de espiguetas com cariopse $\times 100$ ) / número de espiguetas formadas

\subsubsection{Qualidade das sementes}

Após serem separadas e contadas, as sementes puras foram acondicionadas em envelopes de papel tipo "kraft" e armazenadas sob condições de ambiente, para posterior realização do teste de germinação.

O teste de germinação foi iniciado em $27 / 07 / 94$, após o fim da degrana de todos os ecótipos. O teste foi realizado em caixas "gerbox" com 100 sementes cada ou com o total das sementes puras coletadas, caso essa quantidade fosse inferior a 100 sementes, utilizando-se temperatura alternada $20-35^{\circ} \mathrm{C}$ e iluminação alternada $8 / 16$ horas luz/escuro, sem tratamento para superação de dormência (ácido sulfúrico ou nitrato de potássio). O substrato foi duas folhas de papel "germibox", umedecidos com água destilada, em quantidade equivalente a 2,5 vezes o peso do mesmo, que correspondeu a $15 \mathrm{ml}$

Por ocasião das contagens, caso o substrato apresentasse com umidade insuficiente, a mesma era reposta com água destilada, de forma a manter a umidade homogênea entre os recipientes.

Em função da quantidade de sementes disponível, cada parcela de cada ecótipo correspondeu a uma repetição do teste.A última contagem foi realizada 28 dias após a instalação do teste, visto que aos 21 dias havia diversas sementes em estágio 
inicial de germinação, obtendo-se ao final, os seguintes dados, em porcentagem:
a) plântulas normais (PN);
b) plântulas anormais (PA);
c) sementes mortas $(\mathrm{SM})$;
d) sementes dormentes (SD).

Ao final do teste de germinação, as sementes dormentes foram submetidas ao teste de tetrazólio.

Para tanto as mesmas foram cortadas longitudinalmente com um bisturi, sendo uma das metades imersa em solução de tetrazólio (cloreto de 2,3,5-trifenil tetrazólio - TTC) a $0,075 \%$, e levadas a estufa a $40^{\circ} \mathrm{C}$ durante 3 horas.

Após isto, foram analisadas sob lupa estereoscópica, determinando-se, conforme as Regras para Análise de Sementes (BRASIL, 1992 ):
a) sementes viáveis;
b) sementes inviáveis ou mortas.

No resultado final, as sementes mortas foram consideradas como a soma das sementes mortas do teste de germinação e as sementes inviáveis do teste de tetrazólio. As sementes viáveis do teste de tetrazólio foram consideradas sementes dormentes. 


\section{RESULTADOS E DISCUSSÃO}

\subsection{Fenologia reprodutiva}

A fenologia reprodutiva dos ecótipos foi determinada no segundo ano de florescimento, sendo que no primeiro ano foi registrado a data de IEI e o número de dias decorridos desde a semeadura, como pode ser observado na Tabela 2.

Tabela 2. Data de início de emissão de inflorescências (IEI) de ecótipos de Brachiaria spp. no primeiro ano de florescimento.

\begin{tabular}{|ccc|}
\hline $\begin{array}{c}\text { ECÓTIPO } \\
\text { (BRA) }\end{array}$ & DATA & NDAS* \\
\hline Basilisk & $12 / 01 / 93$ & 68 \\
004391 & $12 / 01 / 93$ & 68 \\
003891 & $15 / 01 / 93$ & 71 \\
002801 & $25 / 01 / 93$ & 81 \\
Marandu & $16 / 02 / 93$ & 103 \\
003484 & $29 / 03 / 93$ & 144 \\
003361 & $14 / 04 / 93$ & 160 \\
004308 & $29 / 04 / 93$ & 175 \\
003441 & $13 / 05 / 93$ & 189 \\
\hline
\end{tabular}

* NDAS $=$ Número de dias após a semeadura $(05 / 11 / 92)$ 
Verifica-se que no primeiro ano de florescimento, não houve uma nítida formação de grupos distintos quanto ao caráter de início de emissão de inflorescências.

A comparação entre o IEI, no primeiro e segundo ano de florescimento, é apresentado na Tabela 3 e demonstrado na Figura 8.

Tabela 3. Data de início de emissão de inflorescências (IEI) de ecótipos de Brachiaria spp. no primeiro e segundo ano de florescimento.

\begin{tabular}{|cccc|}
\hline $\begin{array}{c}\text { ECÓTIPO } \\
\text { (BRA) }\end{array}$ & $\begin{array}{c}\text { PRIMEIRO } \\
\text { ANO }\end{array}$ & $\begin{array}{c}\text { SEGUNDO } \\
\text { ANO }\end{array}$ & $\begin{array}{c}\text { DIFERENÇA } \\
\text { (dias ) }\end{array}$ \\
\hline Basilisk & $12 / 01 / 93$ & $07 / 12 / 93$ & -36 \\
004391 & $12 / 01 / 93$ & $21 / 12 / 93$ & -22 \\
003891 & $15 / 01 / 93$ & $17 / 12 / 93$ & -29 \\
002801 & $25 / 01 / 93$ & $22 / 12 / 93$ & -34 \\
Marandu & $16 / 02 / 93$ & $01 / 02 / 94$ & -15 \\
003484 & $29 / 03 / 93$ & $09 / 02 / 94$ & -38 \\
003361 & $14 / 04 / 93$ & $01 / 02 / 94$ & -46 \\
004308 & $29 / 04 / 93$ & $13 / 04 / 94$ & -16 \\
003441 & $13 / 05 / 93$ & $02 / 05 / 94$ & -11 \\
\hline
\end{tabular}

No segundo ano de florescimento, após corte de uniformização realizado em 14/out., observou-se um adiantamento no IEI de todos os ecótipos, concordando com ANDRADE \& THOMAS (1983) onde os resultados demonstraram que $B$. decumbens cv. Basilisk floresceu em 20/fev., 07/dez. e 10/dez., respectivamente no primeiro, segundo e terceiro ano de cultivo. Tal fato reafirma a presença de uma fase de juvenilidade em $B$. decumbens e $B$. brizantha, concordando novamente com ANDRADE et al. (1983) que trabalharam com B. decumbens. 


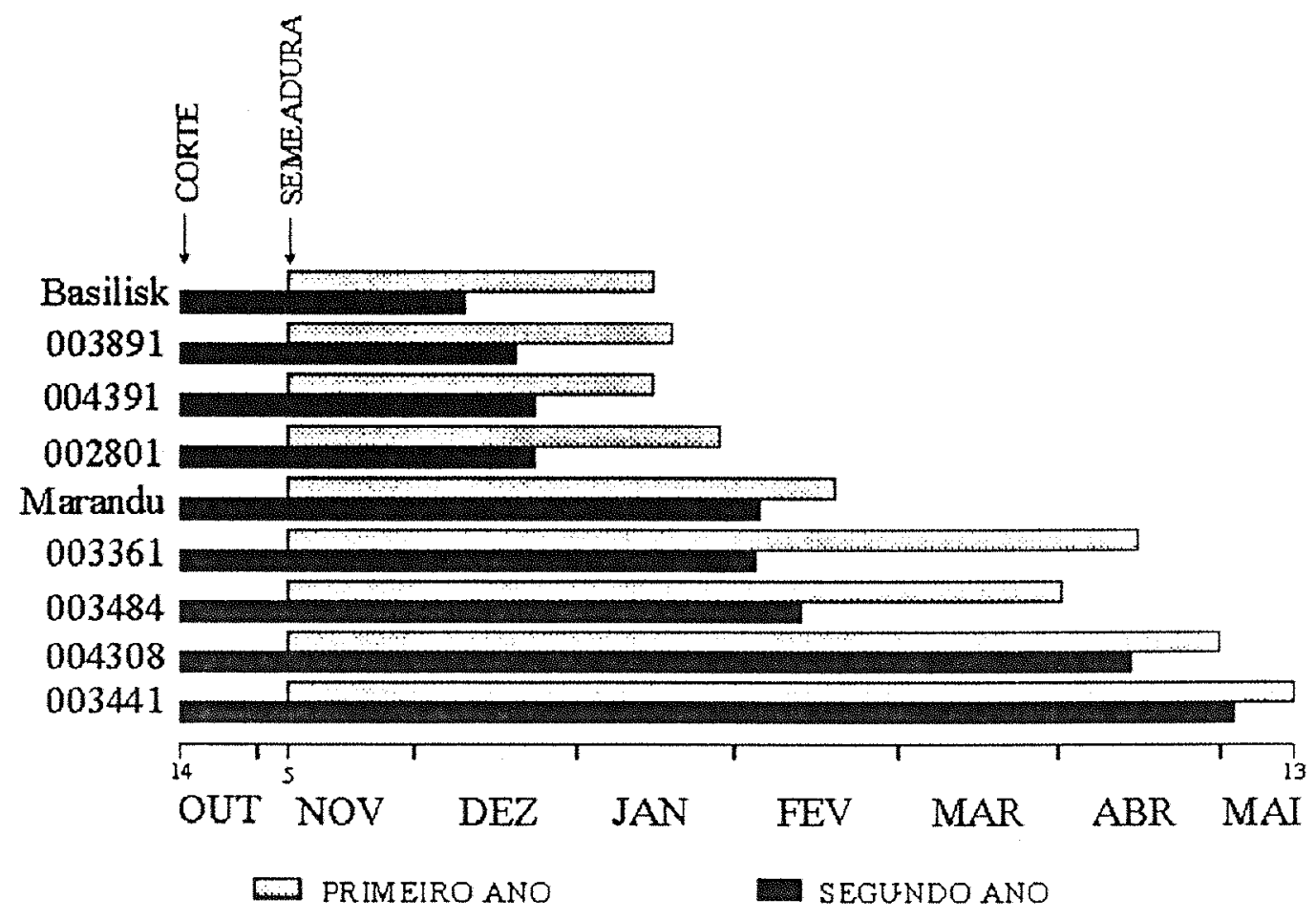

Figura 8. Início de emissão de inflorescência (IEI), no primeiro e segundo ano de florescimento, de ecótipos de Brachiaria spp.

No segundo ano, observou-se um escalonamento da fenologia reprodutiva dos ecótipos, como ilustra a Figura 9, podendo-se identificar 3 grupos distintos, a saber:

- precoces ( Basilisk, 003891, 004391, 002801 ) com IEI $<70$ dias após corte;

- medianos ( Marandu, 003484, 003361 ) com IEI entre 110-120 dias após corte;

- tardios ( 004308, 003441$)$ com IEI > 180 dias após corte. 


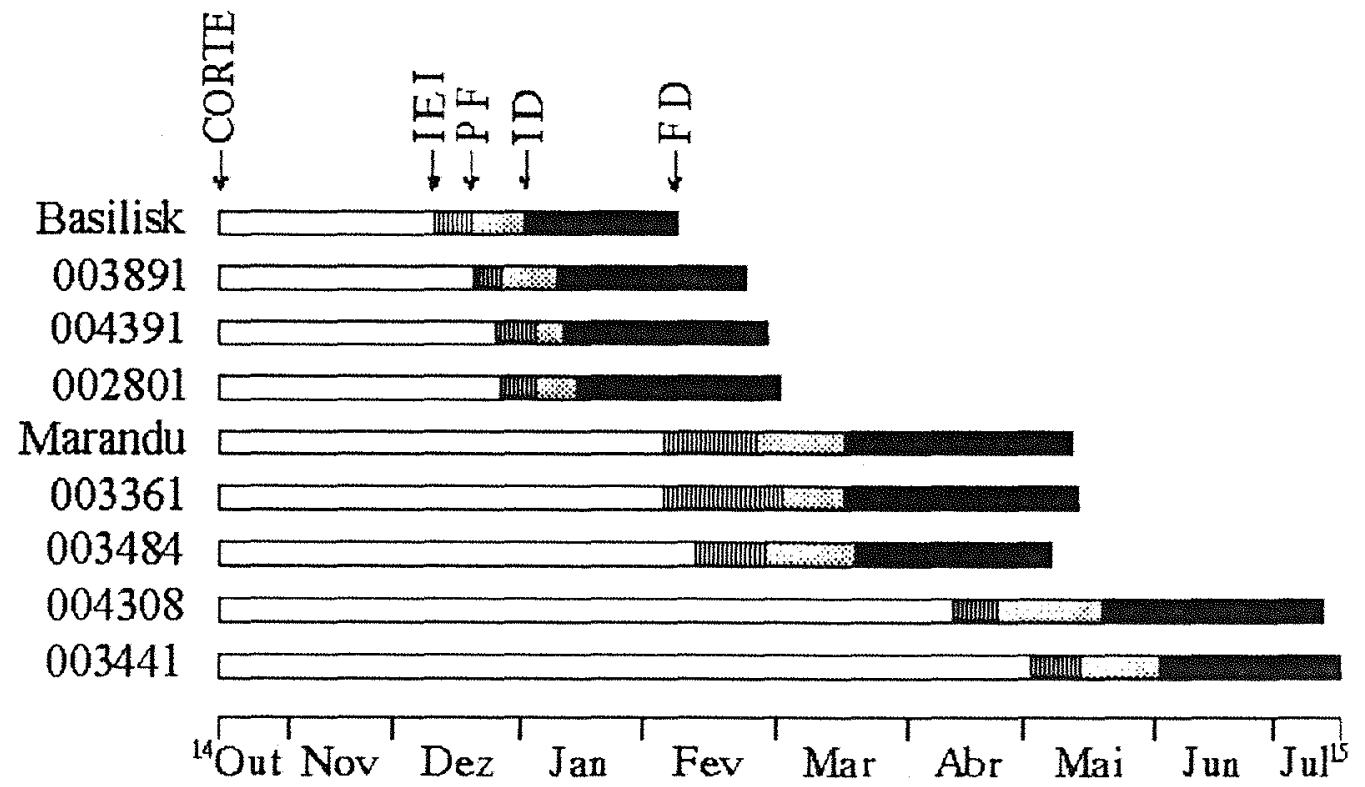

Figura 9. Fenologia reprodutiva de ecótipos de Brachiaria spp., no segundo ano de florescimento.

A cronologia e o número de dias após corte de uniformização, dos parâmetros: IEI, PF, ID e FD, bem como a duração das fenofases: IEI-PF, PF-ID, IDFD e PF-FD são apresentados nas tabelas 4 e 5 , respectivamente.

A fenofase IEI-PF foi marcadamente mais longa nos ecótipos do grupo mediano e, observando-se as Figuras 11 e 12, verifica-se que ocorreu neste período uma elevação na radiação global, além de altas temperaturas, precipitação pluvial e umidade relativa do ar, condições estas favoráveis ao pleno florescimento, indicando uma influência acentuada da carga genética sobre o comportamento dos mesmos.

$\mathrm{O}$ ID e FD referem-se às inflorescências do coletor, sendo que quando da sua observação, já havia degrana em outras inflorescências da parcela, emergidas mais precocemente. Seu valor, portanto, indica o início da fenofase (ID-FD) destas inflorescências específicas. 
Tabela 4. Fenologia reprodutiva de ecótipos de Brachiaria spp., no segundo ano de florescimento.

\begin{tabular}{|ccccc|}
\hline $\begin{array}{c}\text { ECOTIPO } \\
\text { (BRA })\end{array}$ & IEI & PF & ID & FD \\
\hline Basilisk & $07 / 12 / 93^{*}$ & $16 / 12 / 93$ & $30 / 12 / 93$ & $04 / 02 / 94$ \\
& $53 * *$ & 62 & 76 & 112 \\
\hline 003891 & $17 / 12 / 93$ & $23 / 12 / 93$ & $16 / 01 / 94$ & $21 / 02 / 94$ \\
& 63 & 69 & 83 & 129 \\
\hline 004391 & $21 / 12 / 93$ & $31 / 12 / 93$ & $07 / 01 / 94$ & $25 / 02 / 94$ \\
& 67 & 77 & 84 & 133 \\
\hline 002801 & $22 / 12 / 93$ & $31 / 12 / 93$ & $11 / 01 / 94$ & $28 / 02 / 94$ \\
& 68 & 77 & 88 & 136 \\
\hline Marandu & $01 / 02 / 94$ & $22 / 02 / 94$ & $15 / 03 / 94$ & $10 / 05 / 94$ \\
& 109 & 131 & 152 & 208 \\
\hline 003361 & $01 / 02 / 94$ & $02 / 03 / 94$ & $16 / 03 / 94$ & $12 / 05 / 94$ \\
& 109 & 138 & 152 & 209 \\
\hline 003484 & $09 / 02 / 94$ & $25 / 02 / 94$ & $18 / 03 / 94$ & $06 / 05 / 94$ \\
& 117 & 133 & 154 & 203 \\
\hline 004308 & $13 / 04 / 94$ & $22 / 04 / 94$ & $18 / 05 / 94$ & $11 / 07 / 94$ \\
& 180 & 189 & 215 & 269 \\
\hline 003441 & $02 / 05 / 94$ & $13 / 05 / 94$ & $31 / 05 / 94$ & $15 / 07 / 94$ \\
& 199 & 210 & 228 & 273 \\
\hline
\end{tabular}

IEI = Início de emissão de inflorescências

$\mathrm{PF}=$ Pleno florescimento

$\mathrm{ID}=$ Início de degrana

$\mathrm{FD}=$ Fim de degrana

* data cronológica

** número de dias após corte de uniformização (14/10/93)

STÜR (1988) citou que em B. decumbens cv. Basilisk, as espiguetas começam a cair (degrana) 8-11 dias após a emissão das inflorescências e a partir do $11^{\circ}$ dia a degrana ocorre a uma taxa diária de $6 \%$. Observa-se, no entanto, que o ID dessa cultivar, sob as condições apresentadas, deu-se 14 dias após a antese, sendo a taxa diária, se considerada simplesmente como a média diária em função da duração da fenofase 
(ID-FD) de aproximadamente 3\%. O outro ecótipo de B. decumbens (004391) apresentou ID 7 dias após a antese e taxa média diária de $2 \%$.

Tabela 5. Número de dias entre fenofases reprodutivas de ecótipos de Brachiaria spp., no segundo ano de florescimento.

\begin{tabular}{|ccccc|}
\hline $\begin{array}{c}\text { ECOTIPO } \\
\text { (BRA) }\end{array}$ & IEI - PF & PF - ID & ID - FD & PF - FD \\
\hline Basilisk & 9 & 14 & 36 & 50 \\
003891 & 6 & 14 & 46 & 60 \\
004391 & 10 & 7 & 49 & 56 \\
002801 & 9 & 11 & 48 & 59 \\
Marandu & 22 & 21 & 56 & 77 \\
003361 & 29 & 14 & 57 & 71 \\
003484 & 16 & 21 & 49 & 70 \\
004308 & 9 & 26 & 54 & 80 \\
003441 & 11 & 18 & 45 & 63 \\
\hline
\end{tabular}

IEI = Início de emissão de inflorescências;

$\mathrm{PF}=$ Pleno florescimento;

ID = Início de degrana;

$\mathrm{FD}=$ Fim de degrana .

Nos dois ecótipos tardios (004308 e 003441) constatou-se a presença moderada (1-2 focos/inflorescência) de Colletotrichum sp., como infestação secundária de "mela" (Tilletia sp.) nas inflorescências, formando uma camada negra envolvendo as espiguetas. Tal infestação pode ter prolongado a fenofase (ID-FD) desses materiais, uma vez que as espiguetas infestadas apresentavam resistência fisica externa à degrana.

A variação no fotoperíodo, obtida através de tabela apresentada por MOTA (1975) durante as fenofases reprodutivas, pode ser observada na Figura 10. 

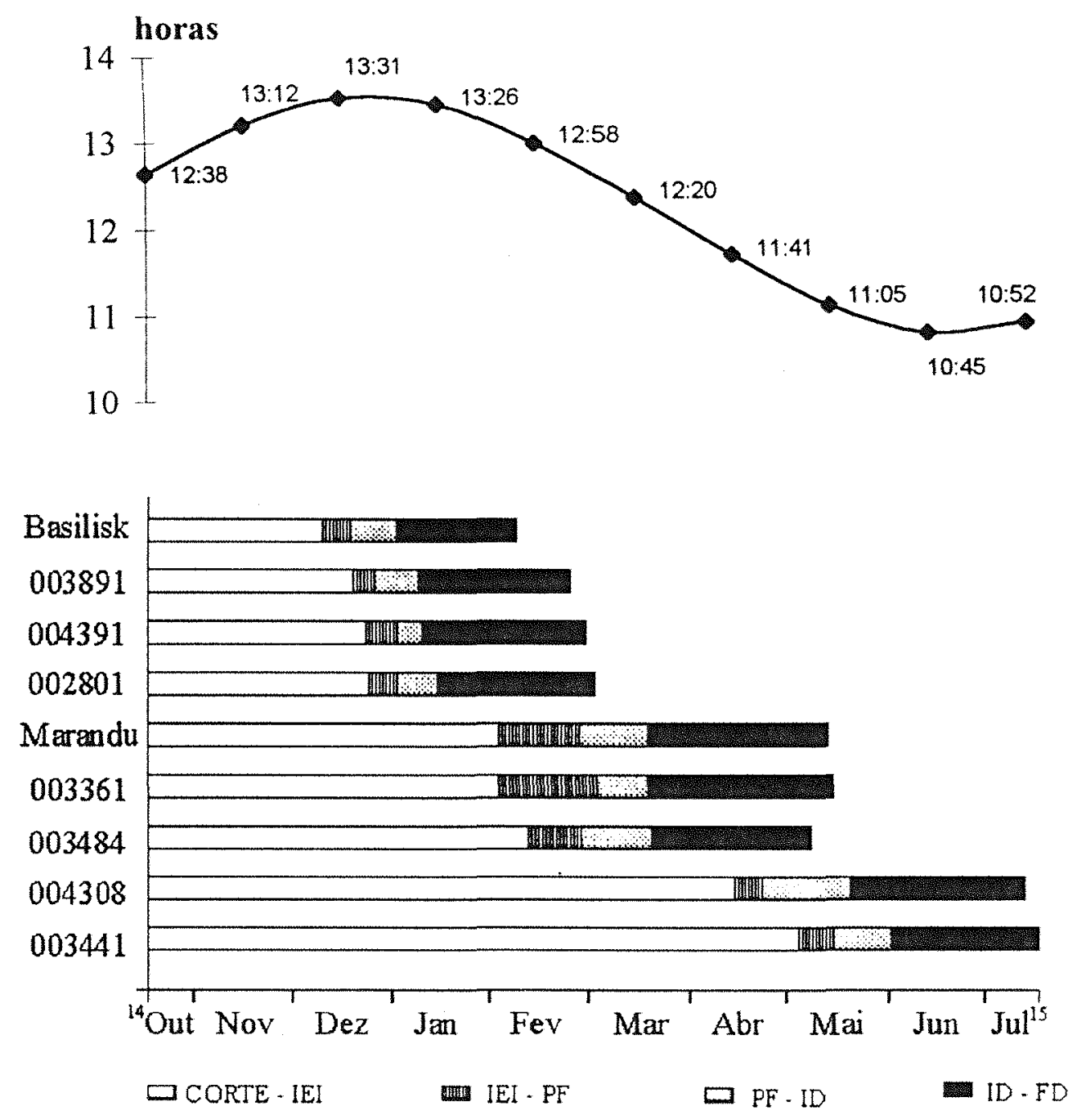

Figura 10. Fotoperiodo (horas), durante as fenofases reprodutivas de ecótipos de Brachiaria spp., no segundo ano de florescimento.

As condições de precipitação pluvial, temperatura média, radiação solar global e umidade relativa do ar, durante as fenofases reprodutivas, no segundo ano de florescimento, são apresentadas nas Figuras 11 e 12. 

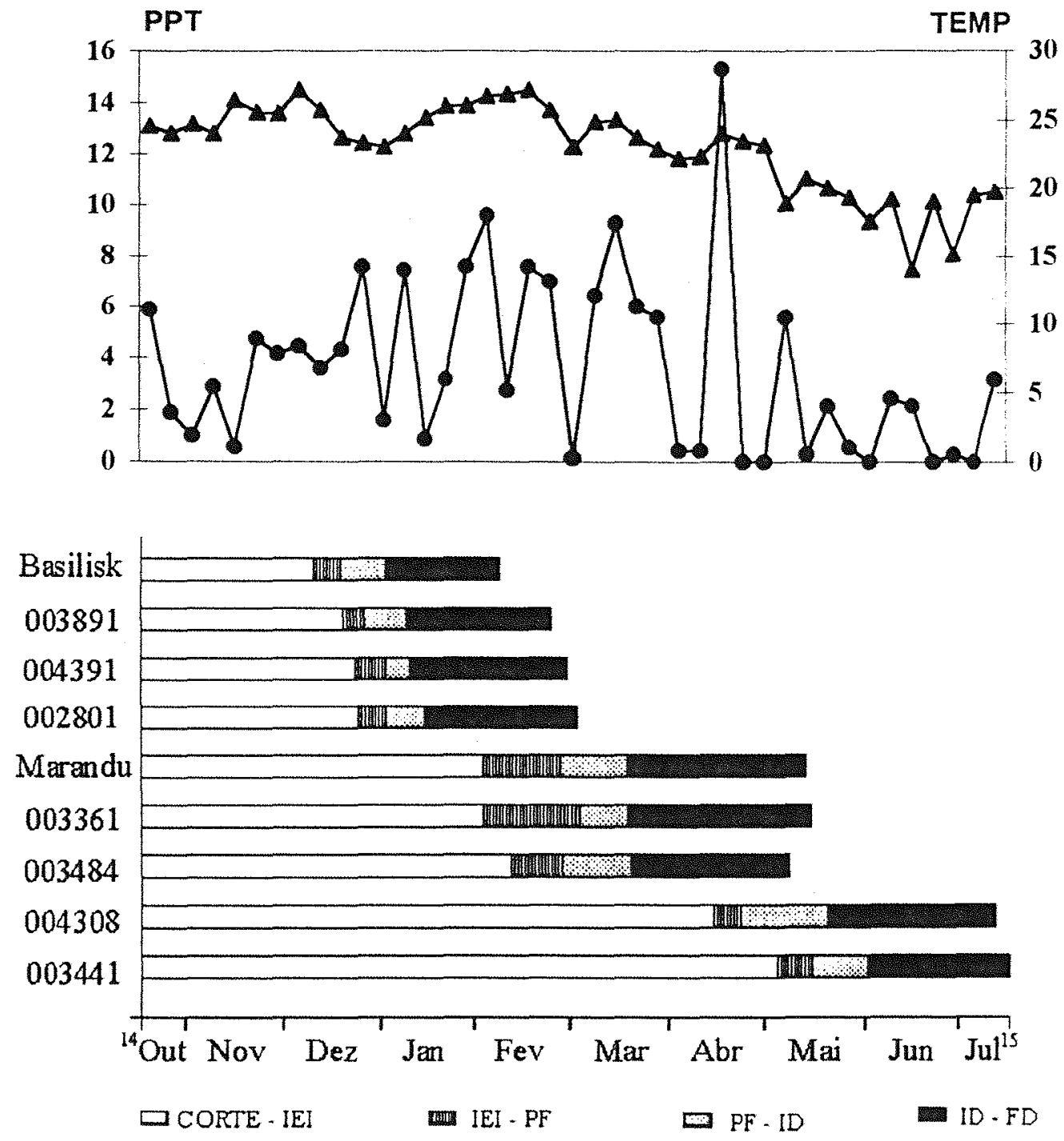

Figura 11. Média semanal de precipitação pluvial (PPT - - , mm) e temperatura média (TEMP $₫,{ }^{\circ} \mathrm{C}$ ), durante as fenofases reprodutivas de ecótipos de Brachiaria spp., no segundo ano de florescimento. 

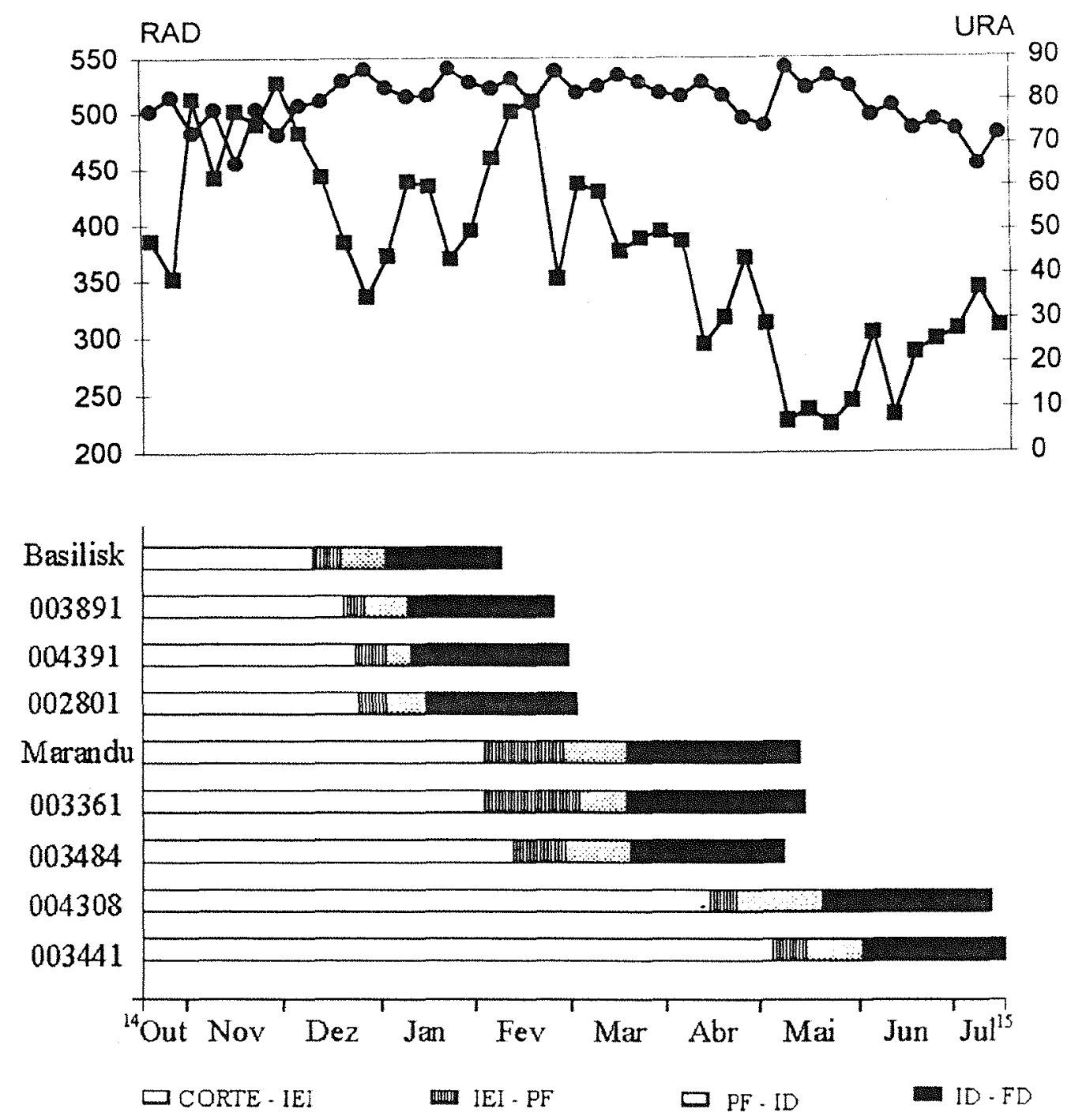

Figura 12. Média semanal de radiação solar global (RAD - cal.cm-2. $\mathrm{d}^{-1}$ ) e umidade relativa do ar (URA $\rightarrow$, \%), durante as fenofases reprodutivas de ecótipos de Brachiaria spp., no segundo ano de florescimento.

A amplitude, média e desvio padrão dos parâmetros e fenofases reprodutivos são apresentados na tabela 10 .

O estudo mais aprofundado da fenologia reprodutiva, requer observações durante vários ciclos de florescimento e o monitoramento das condições climáticas torna- 
se imprescindivel para que se possa detectar e melhor explicar as relações entre o desenvolvimento reprodutivo e as condições de ambiente.

Através do conhecimento da fenologia reprodutiva, pode-se adotar práticas de manejo do campo de produção de sementes, como épocas de corte pré-florescimento, adubação e colheita, visando incrementar a produção e/ou aumentar a eficiência de colheita das sementes.

\subsection{Caracterização morfológica das inflorescências}

As características morfológicas das inflorescências estão apresentadas na Tabela 6.

O número de racemos por inflorescência é extremamente variável, mesmo dentro de um mesmo ecótipo, podendo variar de 1-5 como em Basilisk e Marandu, até 2-10 como em 004308 .

LEITÃO FILHO (1977) caracterizou B. brizantha e B. decumbens, como apresentando, respectivamente, número médio de racemos por inflorescência (NR) igual a 5 e 4, número médio de espiguetas por racemo (NE) igual a 32 e 24 e, comprimento médio dos racemos (CR) igual a 9 e 7cm. STÜR \& HUMPHREYS (1987) encontraram, para o parâmetro NR, uma variação de 1-4 em $B$. decumbens $\mathrm{cv}$. Basilisk.

Comparando-se com os dados obtidos, verifica-se quão ampla é a variabilidade dentro das espécies em questão. Variabilidade esta com aspectos positivos, como possibilidade de melhoramento genético, e negativos, como dificuldade de manejo e colheita. 
Tabela 6. Características morfológicas das inflorescências de ecótipos de Brachiaria spp.

\begin{tabular}{|r|c|c|c|c|c|c|c|c|c|}
\hline \multirow{2}{*}{$\begin{array}{c}\text { PARA } \\
\text { ME }\end{array}$} & \multicolumn{9}{|c|}{ ECOTIPOS (BRA) } \\
\cline { 2 - 11 } & B. decumbens & \multicolumn{7}{|c|}{ B. brizantha } \\
\cline { 2 - 11 } & Basilisk & 004391 & 003891 & 002801 & Marandu & 003361 & 003484 & 004308 & 003441 \\
\hline NR & 3 & 4 & 3 & 4 & 3 & 4 & 5 & 5 & 7 \\
\hline VNR & $1-5$ & $2-8$ & $2-6$ & $2-8$ & $1-5$ & $1-6$ & $1-7$ & $2-10$ & $3-10$ \\
\hline 2 & 39 & 31 & 34 & 30 & 39 & 33 & 30 & 35 & 36 \\
\hline 3 & 41 & 32 & 34 & 32 & 41 & 37 & 35 & 40 & 35 \\
\hline 4 & - & 32 & 32 & 31 & 39 & 36 & 34 & 39 & 33 \\
\hline 5 & - & - & - & - & - & - & 40 & 38 & 34 \\
\hline 6 & - & - & - & - & - & - & - & - & 33 \\
\hline 7 & - & - & - & - & - & - & - & - & 28 \\
\hline média & 40 & 31 & 33 & 31 & 40 & 35 & 35 & 38 & 34 \\
\hline CR 1 & 7,5 & 8,3 & 9,5 & 9,5 & 15,6 & 13,5 & 14,1 & 10,7 & 10,0 \\
\hline 2 & 6,5 & 8,4 & 8,5 & 8,8 & 14,9 & 13,6 & 16,0 & 10,7 & 8,0 \\
\hline 3 & 6,4 & 7,7 & 8,1 & 8,1 & 13,3 & 11,0 & 14,3 & 9,9 & 7,6 \\
\hline 4 & - & 7,8 & - & 8,4 & - & 11,0 & 14,5 & 9,6 & 8,6 \\
\hline 5 & - & - & - & - & - & - & 15,6 & 8,9 & 9,2 \\
\hline 6 & - & - & - & - & - & - & - & - & 9,5 \\
\hline 7 & - & - & - & - & - & - & - & - & 8,0 \\
\hline média & 6,8 & 8,0 & 8,7 & 8,7 & 14,6 & 12,2 & 14,9 & 10,0 & 8,7 \\
\hline CI & 8,0 & 8,8 & 6,9 & 9,9 & 13,6 & 14,4 & 14,4 & 11,5 & 11,4 \\
\hline TFE & dupla & única & única & única & única & única & única & única & única \\
\hline
\end{tabular}

$\mathrm{NR}=$ Número de racemos por inflorescência;

$\mathrm{VNR}=$ Variação do número de racemos por inflorescência;

$\mathrm{NE}=$ Número de espiguetas por racemo;

$\mathrm{CR}=$ Comprimento do racemo $(\mathrm{cm})$;

$\mathrm{CI}=$ Comprimento da inflorescência $(\mathrm{cm})$;

TFE $=$ Tipo de fila de espiguetas.

Através de observações, verificou-se uma tendência das primeiras inflorescências emitidas apresentarem maior NR que as emitidas mais tardiamente. Essa característica foi especialmente acentuada em Basilisk. STÜR \& HUMPHREYS (1987) 
verificaram em $B$. decumbens cv. Basilisk, a mesma tendência quanto aos parâmetros comprimento do racemo e número de espiguetas por racemo, ou seja, esses caracteres eram maiores nas inflorescências emergidas mais precocemente.

$\mathrm{Na}$ maioria dos ecótipos, o NE entre os diversos racemos da inflorescência foi semelhante, como pode ser verificado na Tabela 6, onde, à exceção de 003484 , 004308 e 003441 , que são os ecótipos mais tardios, a variação do NE foi, no máximo igual a 4 espiguetas.

As variações quanto ao NE dos ecótipos, além da própria fisiologia da planta, são relacionadas também, conforme citou STÜR \& HUMPHREYS (1987) com mudanças no ambiente durante a fase de diferenciação das espiguetas.

Observou-se também, na maioria dos ecótipos, uma tendência de diminuição do CR à medida que os mesmos são formados, ou seja, os racemos 1, formados primeiramente, são maiores que os racemos 2 , formados posteriormente, e assim sucessivamente.

As cultivares Marandu e Basilisk apresentaram a mesma média de NE (40) sendo que Marandu apresentou como média de CR $(14,6)$ mais que o dobro de Basilisk $(6,8)$. Tal fato pode surpreender. No entanto, devemos considerar que Marandu possui tipo de fila de espiguetas (TFE) única, enquanto que Basilisk possui tipo dupla.

Os parâmetros relacionados com as dimensões da inflorescência ( $\mathrm{CR}$ e CI) são distintamente maiores nos ecótipos do grupo mediano (Marandu, 003361 e 003484 ), no entanto, o número de espiguetas por comprimento de racemo nesse grupo foi inferior aos demais ecótipos, ou seja, a densidade de espiguetas por racemo é menor no grupo mediano.

Alguns caracteres fenológicos, como a duração das fenofases, e morfológicos, como NR, NE e peso de sementes, são bastante influenciados pelas 
condições de ambiente e não caracterizam determinado ecótipo/cultivar, no entanto, expressam o seu comportamento nas condições a que foram submetidos.

A amplitude, média e desvio padrão, dos parâmetros morfológicos são apresentados na Tabela 10 .

\subsection{Componentes da produção de sementes}

Todos os componentes da produção de sementes apresentaram grande variação, e entre ecótipos, como mostra a Tabela 7.

Tabela 7. Componentes da produção de sementes, por inflorescência, de ecótipos de Brachiaria spp.

\begin{tabular}{|cccccc|}
\hline $\begin{array}{c}\text { ECOTIPO } \\
(\text { BRA })\end{array}$ & NTP & $\begin{array}{c}\text { SP } \\
(\%)\end{array}$ & $\begin{array}{c}\text { EC } \\
(\%)\end{array}$ & $\begin{array}{c}\text { PRI } \\
(\%)\end{array}$ & $\begin{array}{c}\text { AB } \\
(\%)\end{array}$ \\
\hline Basilisk & 111 & 21 & 65 & 14 & 76 \\
003891 & 124 & 13 & 49 & 38 & 79 \\
004391 & 134 & 12 & 51 & 37 & 81 \\
002801 & 148 & 25 & 54 & 21 & 68 \\
Marandu & 160 & 26 & 56 & 18 & 69 \\
003361 & 157 & 9 & 63 & 28 & 88 \\
003484 & 159 & 9 & 60 & 31 & 86 \\
004308 & 134 & 45 & 51 & 4 & 53 \\
003441 & 247 & 36 & 56 & 8 & 61 \\
\hline
\end{tabular}

NTP = Número total de pedicelos;

$\mathrm{SP}=$ Sementes puras;

$\mathrm{EC}=$ Espiguetas chochas;

PRI = Primórdios de espiguetas;

$\mathrm{AB}=$ Taxa de aborto. 
O número total de pedicelos (NTP) apresentou uma tendência de aumento, das precoces às tardias, visto também que $\mathrm{NR}$ e $\mathrm{CR}$, aumentaram no mesmo sentido.

Os componentes da produção de sementes, SP, EC e PRI não demonstraram tendência clara de diferenciação em função da precocidade dos ecótipos.

Os resultados obtidos quanto a SP, demonstram novamente, a ampla variabilidade entre os ecótipos e, quando CROWDER \& CHHEDA (1982) afirmaram que em gramíneas tropicais disponiveis, tal parâmetro geralmente não ultrapassa 15-20\%, encontramos na maioria dos materiais, valores superiores, sendo que os dois mais tardios (004308 e 003441) apresentaram mais que o dobro dessa porcentagem (45 e 36\%).

Em todos os ecótipos, EC foi o componente da produção de sementes em maior porcentagem, sendo $\mathrm{AB}$ em Basilisk (24\%) semelhante à obtida por STÜR \& HUMPHREYS (1985) que foi de $22 \%$.

BOONMAN (1971) afirmou que as espécies pertencentes à tribo Paniceae apresentam um baixo potencial para produção de sementes, no entanto, verificamos que principalmente o aproveitamento do potencial de produção é baixo, seja devido à elevada taxa de aborto ou mesmo a dificuldades na colheita das sementes produzidas.

A maioria dos PRI localizam-se na base do racemo, próximos ao eixo da inflorescência, podendo no entanto, também ser encontrados na base do racemo, seguindo-se de EC e após estas, novamente PRI, demonstrando uma falta de sequência lógica quanto à localização desses componentes no racemo.

O número de sementes por grama (NSPG) e o peso de 100 sementes (P100) são apresentados na Tabela 8.

Notou-se uma tendência de aumento no peso das sementes nos ecótipos mais tardios, sendo bastante nítido nos ecótipos 004308 e 003441 . Não foi determinado a 
umidade das sementes, podendo ser que as mais tardias estivessem com maior teor de água, no entanto, através de análise visual, verificou-se um tamanho maior das mesmas.

Tabela 8. Número de sementes por grama e peso de 100 sementes de ecótipos de Brachiaria spp.

\begin{tabular}{|ccc|}
\hline $\begin{array}{c}\text { ECOTIPO } \\
\text { (BRA) }\end{array}$ & SEMENTES / GRAMA & PESO 100 SEMENTES \\
\hline Basilisk & 177 \\
003891 & 148 & 0,56 \\
004391 & 153 & 0,58 \\
002801 & 113 & 0,66 \\
Marandu & 122 & 0,89 \\
003361 & 101 & 0,82 \\
003484 & 120 & 0,99 \\
004308 & 89 & 0,83 \\
003441 & 85 & 1,13 \\
\hline
\end{tabular}

Os componentes da produção de sementes parecem estar mais fortemente relacionados com propriedades fisiológicas, inerentes de cada ecótipo, do que a condições climáticas sob as quais os mesmos estão expostos, visto que dentro de um mesmo grupo, onde as fenofases reprodutivas se deram sob condições de certa forma semelhantes, os componentes apresentaram ampla variação. No entanto, pode ser que uma variação breve em algum componente climático, em determinada fase crítica do desenvolvimento reprodutivo, possa afetar especificamente determinado ecótipo, favorecendo ou prejudicando os componentes da produção de sementes do mesmo.

Verificou-se que alguns materiais apresentaram um maior potencial de produção de sementes puras, com SP $>20 \%$, se comparado com o das cultivares hora disponiveis, enquanto que outros mostraram menor potencial. Tal informação é importante como ferramenta para trabalhos de seleção e/ou melhoramento, podendo os materiais serem explorados conforme o objetivo em questão, pois nem sempre uma alta 
produção de sementes puras é o desejável. No caso da prática de rotação pecuária/lavoura, uma menor produção de SP é melhor, visto que a erradicação da forrageira pode ser um problema para o estabelecimento da próxima cultura. No entanto, essa característica certamente aumentará o custo final de produção de sementes, podendo prejudicar a adoção do material por parte dos pecuaristas.

A amplitude, média e desvio padrão, dos parâmetros de componentes da produção de sementes, são apresentados na Tabela 10.

\subsection{Qualidade das sementes}

Os resultados dos testes de germinação e de tetrazólio são apresentados na Tabela 9.

Tabela 9. Resultados de teste de germinação e de tetrazólio em sementes de ecótipos de Brachiaria spp.

\begin{tabular}{|cccccc|}
\hline $\begin{array}{c}\text { ECOTIPO } \\
(\text { BRA })\end{array}$ & $\begin{array}{c}\text { PN } \\
(\%)\end{array}$ & $\begin{array}{c}\text { PA } \\
(\%)\end{array}$ & $\begin{array}{c}\text { SD } \\
(\%)\end{array}$ & $\begin{array}{c}\text { SM } \\
(\%)\end{array}$ & $\begin{array}{c}\text { PN + SD } \\
(\%)\end{array}$ \\
\hline Basilisk & 15 & 14 & 19 & 52 & 34 \\
003891 & 7 & 11 & 54 & 28 & 61 \\
004391 & 4 & 10 & 56 & 30 & 60 \\
002801 & 66 & 4 & 19 & 11 & 85 \\
Marandu & 32 & 9 & 30 & 29 & 62 \\
003361 & 44 & 4 & 30 & 22 & 74 \\
003484 & 10 & 4 & 36 & 50 & 46 \\
004308 & 33 & 6 & 41 & 20 & 74 \\
003441 & 28 & 3 & 30 & 39 & 58 \\
\hline
\end{tabular}

$\mathrm{PN}=$ Plântulas normais;

PA = Plântulas anormais;

$\mathrm{SD}=$ Sementes dormentes;

$\mathrm{SM}=$ Sementes mortas. 
Novamente observa-se uma grande variabilidade nos resultados apresentados pelos ecótipos.

Observa-se que os três ecótipos mais precoces (Basilisk, 003891, 004391) juntamente com o mediano 003484, apresentaram as menores porcentagens de PN.

Observações acerca da dormência de sementes são apenas exploratórias, visto que, por apresentarem idades e consequentemente períodos de armazenamento diferentes, qualquer inferência sobre o nível de dormência das mesmas seria irreal.

Dois ecótipos do grupo precoce (003891 e 004391) mesmo permanecendo armazenados durante um período bem superior aos demais grupos (5 meses) apresentaram as maiores porcentagens de sementes dormentes (SD) demonstrando, talvez, uma grande variação no nível de dormência das sementes entre os materiais.

$\mathrm{Na}$ Tabela 9, foi incluído a coluna (PN+SD) objetivando dar uma idéia do potencial de germinação dos ecótipos, visto que a porcentagem de PA é bastante reduzida e as sementes que se apresentavam dormentes por ocasião dos testes, têm grandes possibilidades de originar plântulas normais, uma vez superado este estágio de dormência.

É interessante observar que os ecótipos 004391 e 002801, apesar de apresentarem fenofases reprodutivas bem semelhantes, produziram sementes com aspectos qualitativos totalmente diferentes, sendo que o primeiro apresentou a menor porcentagem de $\mathrm{PN}$ e a maior de $\mathrm{SD}$, enquanto que o segundo apresentou a maior porcentagem de $\mathrm{PN}$ e a menor de SD.

Sabendo-se que qualidade de sementes é um termo amplo, englobando aspectos genéticos, físicos, fisiológicos e sanitários das mesmas e que a qualidade fisiológica não pode ser totalmente explicitada através, somente, de testes de germinação e de tetrazólio, os resultados apresentados visam apenas verificar a amplitude de resposta 
das sementes dos ecótipos, aos referidos testes, além de fazer alguns comentários exploratórios sobre os resultados dos mesmos.

A amplitude, média e desvio padrão, dos parâmetros de qualidade das sementes, são apresentados na Tabela 10.

Tabela 10. Amplitude, média e desvio padrão dos caracteres analisados, no segundo ano de florescimento.

\begin{tabular}{|c|c|c|c|}
\hline CARACTERES & AMPLITUDE & MEDIA & DESVIO PADRÃO \\
\hline IEI & $53-199$ & 107 & 52,3 \\
\hline PF & $62-210$ & 121 & 53,8 \\
\hline ID & $76-228$ & 137 & 58,0 \\
\hline FD & $112-273$ & 186 & 61,0 \\
\hline IEI - PF & $6-29$ & 13 & 7,5 \\
\hline PF - ID & $7-26$ & 16 & 5,8 \\
\hline ID - FD & $36-57$ & 49 & 6,4 \\
\hline PF - FD & $50-80$ & 65 & 10,0 \\
\hline NR & $3-7$ & 4 & 1,3 \\
\hline NE média & $31-40$ & 35 & 3,5 \\
\hline CR média & $6,8-14,9$ & 10,3 & 2,9 \\
\hline CI & $6,9-14,4$ & 11,0 & 2,8 \\
\hline NTP & $111-247$ & 153 & 39,2 \\
\hline SP & $9-45$ & 22 & 12,6 \\
\hline EC & $49-65$ & 56 & 5,6 \\
\hline PRI & $4-38$ & 22 & 12,2 \\
\hline AB & $53-88$ & 73 & 11,6 \\
\hline NSPG & $85-177$ & 123 & 30,9 \\
\hline P100 & $0,56-1,17$ & 0,86 & 0,2 \\
\hline PN & $4-66$ & 27 & 20,1 \\
\hline PA & $3-14$ & 7 & 3,9 \\
\hline SD & $19-56$ & 35 & 13,4 \\
\hline SM & $11-52$ & 31 & 13,6 \\
\hline PN + SD & $34-85$ & 62 & 15,3 \\
\hline
\end{tabular}


Todas as observações realizadas demonstraram a presença de grande variabilidade dentro e entre os ecótipos, seja em aspectos de fenologia e morfologia reprodutivas, como em componentes da produção e qualidade de sementes. Fato este que discorda de USBERTI FILHO (1992) que afirmou haver pequena variabilidade dentro de ecótipos.

A metodologia utilizada pode ser aprimorada em diversos aspectos, a saber:

a) devido à grande variabilidade existente, mesmo dentro de um ecótipo, as observações quanto às características morfológicas e aos componentes da produção de sementes deverão ser realizadas em um maior número de inflorescências por repetição;

b) a obtenção de maior quantidade de sementes puras possibilitarão a realização de testes de qualidade com repetições e consequentemente com maior segurança;

c) a contagem do número de perfilhos férteis, bem como a porcentagem destes serão importantes para melhor caracterização;

d) a realização de ensaios dessa natureza em outros ecossistemas permitirão uma visão mais segura acerca das influências do meio ambiente sobre os caracteres estudados. 


\section{CONCLUSÕES}

As conclusões, num trabalho exploratório ou básico, são informativas, não permitindo ao autor, inferir sobre determinadas relações, que porventura existam entre os parâmetros observados.

As principais evidências do trabalho são:

a) Os nove materiais analisados se dividiram em três grupos, quanto ao início de florescimento, sendo:

- Precoces - B. decumbens cv Basilisk

B. decumbens 004391

B. brizantha 003891

B. brizantha 002801

- Medianos - B. brizantha cv. Marandu

B. brizantha 003484

B. brizantha 003361

- Tardios - B. brizantha 004308

B. brizantha 003441

b) Verificou-se, no segundo ano, um adiantamento quanto a data de florescimento, evidenciando a existência de uma fase de juvenilidade nos materiais analisados. Fase esta de duração variável entre os mesmos. 
c) Existe uma grande variabilidade dentro e entre os ecótipos de Brachiaria spp. analisados, seja quanto a parâmetros de fenologia reprodutiva (IEI, $\mathrm{PF}, \mathrm{ID}, \mathrm{FD})$, morfologia reprodutiva (NR, NE, CR, Cl), componentes da produção de sementes (SP, EC, PRI) ou qualidade das sementes (PN, PA, SM, SD). 


\section{REFERÊNCIAS BIBLIOGRÁFICAS}

ALCÂNTARA, P. B. Origem das braquiárias e suas caracteristicas morfológicas de interesse forrageiro. In: ENCONTRO SOBRE CAPINS DO GÊNERO BRACHIARIA, 1.,Nova Odessa, 1986. Anais. Nova Odessa, Instituto de Zootecnia, 1987. p.1-18.

ALLARD, R. W. Population structure and sampling methods. In: FRANKEL, O. H. \& BENNETT, E. eds. Genetic resources in plants. Oxford, Blackwell, 1970. p.97107.

ALMEIDA, S. P. de. Grupos fenológicos da comunidade de gramíneas perenes de um campo cerrado no Distrito Federal, Brasil. Pesquisa Agropecuária Brasileira, Brasília, 1995. (No prelo)

ANDRADE, R. P. de. Tecnologia de produção de sementes de espécies do gênero Brachiaria. In: SIMPÓSIO SOBRE MANEJO DA PASTAGEM, 11., Piracicaba, 1994. Anais. Piracicaba, FEALQ, 1994. p.49-71. 
ANDRADE, R. P. de \& THOMAS, D. Pesquisas em avaliação de pastagens e produção de sementes de forrageiras no Centro de Pesquisa Agropecuária dos Cerrados. In: CURSO SOBRE PRODUÇÃO E TECNOLOGIA DE SEMENTES DE FORRAGEIRAS TROPICAIS E SUBTROPICAIS, Porto Alegre, Ijuí, 1981. Trabalhos apresentados. Ijuí, COTRIJUÍ,UFRGS,FAO, 1983. p.82-95.

ANDRADE, R. P. de; THOMAS, D.; FERGUSON, J. E. Seed production of pasture species in a tropical savanna region of Brazil. II. Grasses. Tropical Grasslands, Brisbane, 17(2):59-64, 1983.

ARONOVICH, S. \& ROCHA, G. L. Gramíneas e leguminosas forrageiras de importância no Brasil Central pecuário. Informe Agropecuário, Belo Horizonte, 11(132):3-12, 1985.

BARCELLOS, A. O. \& VILELA, L. Leguminosas forrageiras tropicais: Estado de arte e perspectivas futuras. In: SIMPÓSIO INTERNACIONAL DE FORRAGICULTURA, Maringá, 1994. Trabalhos apresentados. Maringá, Universidade Estadual de Maringá, 1994, p.1-56.

BOONMAN, J. G. Experimental studies on seed production of tropical grasses in Kenya. 1. General introduction and analysis of problems. Netherlands Journal of Agricultural Science, Wageningen, 19:23-36, 1971. 
BOONMAN, J. G. Produção de sementes de forrageiras tropicais na África, com referência especial ao Kênia. In: SÁNCHEZ, P. A.; TERGAS, L. E.; SERRÃO, E. A. S., ed. Produção de pastagens em solos ácidos dos trópicos. Brasilia, Editerra Ed., 1982. p.393-410.

BRASIL. Ministério da Agricultura. Regras para análise de sementes. Brasília, Departamento Nacional de Produção Vegetal, 1992. 365p.

CANI, P. C. Influência do nitrogênio, cortes e época de corte sobre a produção e qualidade de sementes do capim braquiária (Brachiaria decumbens Stapf). Viçosa, 1980. (Mestrado - Universidade Federal de Viçosa).

CARVALHO, N. M. de \& NAKAGAWA, J. Sementes: ciência, tecnologia e produção. Campinas, Fundação Cargill, 1980. 326p.

CASTRO, R. D. de. Influência de métodos e épocas de colheita sobre a produção e qualidade de sementes de Brachiaria (Brachiaria decumbens ). Lavras, 1992. 73p. (Mestrado - Escola Superior de Agricultura de Lavras).

CHRISTIANSEN, S. Letter from the editors. Dryland Pasture \& Forage Legume Network News, Aleppo, (10):2, Dec. 1994.

CONDÉ, A. R. Produção de sementes de forrageiras no Cerrado. In: SIMPÓSIO NACIONAL SOBRE SEMENTES DE FORRAGEIRAS, 2., Nova Odessa, 1982. Trabalhos apresentados. Nova Odessa, Instituto de Zootecnia, 1982. p.51-66. 
CROWDER, L. V. \& CHHEDA, H. R. Seed production, multiplication and processing. In: Tropical grassland husbandry. New York, Longman, 1982. cap. 18, p.507-47.

EMPRESA BRASILEIRA DE PESQUISA AGROPECUÁRIA. Centro Nacional de Pesquisa de Gado de Corte, Campo Grande. Relatório técnico anual, Campo Grande, 1985. 194p.

FONT QUER, P. Diccionario de Botánica. Barcelona, Ed. Labor, 1989. 1244p.

FRANÇA-DANTAS, M. S.; GROF, B.; SOUZA, M. A. de. Novo germoplasma de Brachiaria introduzido no Brasil. In: REUNIÃO ANUAL DA SOCIEDADE BRASILEIRA DE ZOOTECNIA, 24., Brasília, 1987. Anais. Brasília, SBZ, 1987. p.219.

FUNDAÇÃO INSTITUTO BRASILEIRO DE GEOGRAFIA E ESTATÍSTICA. Anuário Estatístico do Brasil, Rio de Janeiro, 53:3/62, 1993.

FUNDAÇÃO INSTITUTO BRASILEIRO DE GEOGRAFIA E ESTATÍSTICA. Censo agropecuário - 1985. Rio de Janeiro, 1985.

GARCIA, R.; CANI, P. C.; OBEID, J. A.; SILVA, R. F. da. Influência do nitrogênio, cortes e épocas de colheita sobre a produção de sementes do capim braquiária (Brachiaria decumbens Stapf). Revista da Sociedade Brasileira de Zootecnia, Viçosa, 18(6):482-90, 1989. 
GHISI, O. M. A. A. Brachiaria na pecuária brasileira: Importância e perspectivas. In: ENCONTRO PARA DISCUSSÃO SOBRE CAPINS DO GÊNERO BRACHIARIA, Nova Odessa, 1991. Anais. Nova Odessa, Instituto de Zootecnia, 1991. p.1-43.

GIACOMETTI, D. C. Introdução e intercâmbio de germoplasma. In: ENCONTRO SOBRE RECURSOS GENÉTICOS, 1., Jaboticabal, 1988. Anais. Jaboticabal, UNESP/FCAV, 1988, p.43-55.

HESKETH, J. D. Limitations to photosynthesis responsible for differences among species. Crop Science, Madison, 4:493, 1963.

HOPKINSON, J. M. \& EAGLES, D. A. Seed production and processing. In: CLEMENTS, R. J. \& CAMERON, D. G., ed. Collecting and testing tropical forage plants. Melbourne, CSIRO, 1990. cap.8, p.88-101.

HOPKINSON, J. M. \& ENGLISH, B. H. Harvest efficiency in seed crops of gaton panic (Panicum maximum) and signal grass (Brachiaria decumbens). Tropical Grasslands, Brisbane. 16(2):201-7, 1982.

HUMPHREYS, L. R. Tropical pasture seed production. Rome, FAO, 1979. 143p. (Plant Production and Protection Paper, 8)

HUMPHREYS, L. R. Tropical pasture and fodder crops. 2. ed. Essex, Longman, 1987. $155 \mathrm{p}$. 
ISON, R. L. \& HOPKINSON, J. M. Pasture legumes and grasses of warm climate regions. In: HALEVY, A. H., ed. CRC handbook of flowering. Boca Raton, CRC Press, 1985. v.1, p.203-51.

JAIN, S. K. Population structure and the effects of the breeding system. In: FRANKEL, O. H. \& HAWKES, J. G. eds. Crop genetic resources for today and tomorrow. Cambridge, Cambridge University Press, 1975. p.15-36.

LEITÃO FILHO, H. de F. Espécies do gênero Brachiaria Griseb nativas e exóticas cultivadas no Estado de São Paulo. 2. ed. Campinas, CATI, 1977. 27p. (CATI. Boletim Técnico, 97).

LEITE, G. G. \& EUCLIDES, V. P. Utilização de pastagens de Brachiaria spp. In: SIMPÓSIO SOBRE MANEJO DA PASTAGEM, 11., Piracicaba, 1994. Anais. Piracicaba, FEALQ, 1994. p.267-97.

LLERAS, E. Coleta de recursos genéticos vegetais. In: ENCONTRO SOBRE RECURSOS GENÉTICOS, 1., Jaboticabal, 1988. Anais. Jaboticabal, UNESP/FCAV, 1988, p.23-42.

LLERAS, E.; CORADIN, L.; HAY, J.D. Development of germplasm sampling strategies for tropical perennials: a proposal. In: SIMPÓSIO DO TRÓPICO ÚMIDO, 1, Belém, 1984. Anais. Brasília, EMBRAPA/DDT, 1986. p. 27-38. 
MARCOS FILHO, J.; CICERO, S. M.; SILVA, W. R. da. Avaliação da qualidade de sementes. Piracicaba, FEALQ, 1987.230p.

MARSHALL, D. R. \& BROWN, A. D. H. Optimum sampling strategies in genetic conservation. In: FRANKEL, O. H. \& HAWKES, J. G. eds. Crop genetic resources for today and tomorrow. Cambridge, Cambridge University Press, 1975. p. 53-80.

MARSHALL, D. R. \& BROWN, A. D. H. Theory of forage plant collection. In: McIVOR, J. G. \& BRAY, R. A. eds. Genetic resources of forage plants. East Melbourne, CSIRO, 1983. p.135-48.

MOTA, F. S. da. Radiação solar e plantas cultivadas. In: Meteorologia agrícola. São Paulo, Nobel, 1975. cap.7, p.63-153.

NAKAGAWA, J.; GONÇALEZ, D. A.; LAVEZZO, W.; SILVEIRA, A. C. Efeito da época de colheita sobre a produção e qualidade das sementes de Brachiaria brizantha (Hochst) Stapf. Revista da Sociedade Brasileira de Zootecnia, Viçosa, 10(3):503-12, 1981.

OLIVEIRA, M. P. de. Comércio de sementes movimenta US\$240 milhões por ano no país. Folha de S. Paulo, São Paulo, 12 abr. 1994a. Agrofolha, p. 3.

OLIVEIRA, M. P. de. MS exporta capim para as Américas. Folha de S. Paulo, São Paulo, 22 mar. 1994b. Agrofolha, p. 6. 
PASCHOAL, A. D. Prefácio do tradutor. In: MOONEY, P. R. O escândalo das sementes: o domínio na produção de alimentos. São Paulo, Nobel, 1987. p.13-26.

PATERNIANI, E. Diversidade genética em plantas cultivadas. In: ENCONTRO SOBRE RECURSOS GENÉTICOS, 1., Jaboticabal, 1988. Anais. Jaboticabal, UNESP/FCAV, 1988, p.75-7.

PEREIRA, J. P. Adubação de capins do gênero Brachiaria. In: ENCONTRO SOBRE CAPINS DO GÊNERO BRACHIARIA, 1., Nova Odessa, 1986. Anais. Nova Odessa, Instituto de Zootecnia, 1987. p.117-96.

PRIMO, A. T. Fatores limitantes na produção de sementes de forrageiras. In: SIMPÓSIO SOBRE PRODUÇÃO DE SEMENTES DE FORRAGEIRAS, 2., Nova Odessa, 1982. Trabalhos apresentados. Nova Odessa, Instituto de Zootecnia, 1982. p.71-5.

RATHCKE, B. \& LACEY, E. P. Phenological patterns of terrestrial plants. Annual Review of Ecology and Systematics, Palo Alto, 16:179-214, 1985.

REIS, R. A. Efeitos dos regimes de cortes nos níveis de carboidratos totais nãoestruturais e na produção de sementes do capim-braquiária (Brachiaria decumbens Stapf). Viçosa, 1981. (Mestrado - Universidade Federal de Viçosa).

SALISBURY, F. B. \& ROSS, C. W. Plant physiology. 2 ed. Belmont, Wadsworth Publ., 1978. 422p. 
SALOMON, D. V. Como fazer uma monografia: elementos de metodologia do trabalho científico. 6. ed. Belo Horizonte, Interlivros, 1978. 317p.

SANTOS, N. A. \& AGUIAR, J. L. P. Evolução agropecuária da região dos Cerrados: 1970-80. Planaltina, EMBRAPA/CPAC, 1985. 62p. ( EMBRAPA/CPAC. Documentos, 16 ).

SANTOS FILHO, L. F. Diagnóstico da situação da produção de sementes de plantas forrageiras no Estado de São Paulo. In: ENCONTRO SOBRE PRODUÇÃO DE SEMENTES DE PlaNTAS FORRAGEIRAS, 4., São José do Rio Preto, 1990. Anais. São José do Rio Preto, Editora Só Cópias, 1990. p.1-14A.

SAVIDAN, Y. H. Recursos genéticos. In: SIMPÓSIO SOBRE PRODUÇÃO ANIMAL, 3., Campo Grande, 1986. Anais. Campinas, Fundação Cargill, 1986. p.35-40.

SCHULTZE-KRAFT, R. Recoleción de plantas nativas con potencial forrajero. In: SIMPÓSIO SOBRE PLANTAS FORRAGEIRAS, Campo Grande, 1979. Trabalhos apresentados. Brasilia, EMBRAPA/DID, 1980. p.61-72. (EMBRAPA/CENARGEN. Documentos, 1).

SEIFFERT, N. F. Gramíneas forrageiras do gênero Brachiaria. Campo Grande, EMBRAPA/CNPGC, 1980. 83p. (EMBRAPA/CNPGC. Circular Técnica, 1 ).

SENDULSKY, T. Brachiaria: Taxonomy of cultivated and native species in Brazil. Hoehnea, São Paulo, 7:99-139, 1978. 
SOARES FILHO, C. V. Recomendações de espécies e variedades de Brachiaria para diferentes condições. In: SIMPÓSIO SOBRE MANEJO DA PASTAGEM, 11.,Piracicaba, 1994. Anais. Piracicaba, FEALQ, 1994. p.25-48.

SOUZA, F. H. D. de. Produção de sementes de gramíneas forrageiras no Brasil Central. In: CONGRESSO BRASILEIRO DE PASTAGENS, Piracicaba, 1986. Trabalhos apresentados. Piracicaba, FEALQ, 1986. p. 513-19.

SOUZA, F. H. D. de. As sementes de espécies forrageiras do gênero Brachiaria no Brasil Central. In: ENCONTRO PARA DISCUSSÃO SOBRE CAPINS DO GÊNERO BRACHIARIA, 2., Nova Odessa, 1991. Anais. Nova Odessa, Instituto de Zootecnia, 1991. p.137-85.

STÜR, W. W. Reproductive development of the apex of Brachiaria decumbens Stapf. Annals of Botany, London, 58:569-75, 1986.

STÜR, W. W. \& HUMPHREYS, L. R. Burning, cutting and the structures of seed yield in Brachiaria decumbens. In. INTERNATIONAL GRASSLAND CONGRESS, 15., Kyoto, 1985. Proceedings. Nagoia, The Japanese Society of Grassland Science, 1985. p.303-4.

STÜR, W. W. \& HUMPHREYS, L. R. Tiller development and flowering in swards of Brachiaria decumbens. Annals of Applied Biology, Cambridge, 110(3):639-44, jun. 1987. 
STÜR, W. W. \& HUMPHREYS, L. R. Burning and cutting management and the formation of seed yield in Brachiaria decumbens. Journal of Agricultural Science, Cambridge, 110:669-72, 1988.

TING, I. P. Plant physiology. Reading, Addison-Wesley Publ., 1982. 642p.

TOLEDO, J. M., ed. Manual para la evaluación agronómica - Red Internacional de Evaluación de Pastos Tropicales ( RIEPT ). Cali, CIAT, 1982. 168p.

USBERTI FILHO, J. A. Melhoramento genético de gramíneas forrageiras tropicais. In: CURSO SOBRE PRODUÇÃO DE SEMENTE DE FORRAGEIRAS, 2., Araçatuba, 1992. Trabalhos apresentados. Araçatuba, SBZ, 1992. p.39-47.

VALLE, C. B. do. Seleção e melhoramento de gramíneas do gênero Brachiaria: Perspectivas de lançamento. In: ENCONTRO SOBRE PRODUÇÃO DE SEMENTES DE PLANTAS FORRAGEIRAS, 4., São José do Rio Preto, 1990. Anais. São José do Rio Preto, Editora Só Cópias, 1990. p.1-16D.

VALLE, C. B. do \& MILES, J. M. Melhoramento de gramíneas do gênero Brachiaria. In: SIMPÓSIO SOBRE MANEJO DA PASTAGEM, 11., Piracicaba, 1994. Anais. Piracicaba, FEALQ, 1994. p.1-23. 
VALLE, C. B. do; SAVIDAN, Y. H.,; JANK, L.; COSTA, J. C. G. da. Introdução, avaliação e melhoramento de espécies do gênero Brachiaria. In: SIMPÓSIO SOBRE PRODUÇÃO ANIMAL, 3., Campo Grande, 1986. Anais. Campinas, Fundação Cargill, 1986. p.41-4.

VALLS, J. F. M. Caracterização morfológica, reprodutiva e bioquímica de germoplasma vegetal. In: ENCONTRO SOBRE RECURSOS GENÉTICOS, 1., Jaboticabal, 1988. Anais. Jaboticabal, UNESP/FCAV, 1988, p.106-28.

WHITEMAN, P. C. \& MENDRA, H. Effects of storage and seed treatments on germination of Brachiaria decumbens. Seed Science and Technology, Zurich, $10(2): 233-42,1982$.

YADAVA, R. B. R.; PATIL, B. D.; VERMA, O. P. S. Seed production technology in forages through chemical regulants: A review. Seed Research, New Delhi, 12(1):1-18, 1984.

ZIMMER, A. H. \& CORREA, E. S. A pecuária nacional, uma pecuária de pasto? In: ENCONTRO SOBRE RECUPERAÇÃO DE PASTAGENS, Nova Odessa, 1993. Anais. Nova Odessa, Instituto de Zootecnia, 1993. p.1-25.

ZIMMER, A. H.; MACEDO, M. C. M; BARCELLOS, A. O.; KICHEL, A. N. Estabelecimento e recuperação de pastagens de Brachiaria. In: SIMPÓSIO SOBRE MANEJO DA PASTAGEM, 11., Piracicaba, 1994. Anais Piracicaba, FEALQ, 1994. p.153-208. 